\title{
The Lac au Renard Tephra Cluster: a record of Lochkovian (Lower Devonian) volcanism in the Indian Point Formation, Gaspe Peninsula, Quebec, Canada
}

\author{
James R. Ebert and DAmon K. Matteson \\ Department of Earth and Atmospheric Sciences, SUNY College at Oneonta, Oneonta, New York 13820-4015, USA \\ Corresponding author <James.Ebert@oneonta.edu>
}

Date received: 27 March 2019 gate accepted: 08 October 2019

\begin{abstract}
Approximately twenty tephra beds, comprising the Lac au Renard Tephra Cluster (new), occur in the Rosebush Cove and Petit Portage members of the Indian Point Formation (Chaleurs Group) on the Gaspe Peninsula of Quebec, Canada. The tephra beds range in thickness from $<1.0 \mathrm{~cm}$ to $82 \mathrm{~cm}$ and occur in a mudrock-dominated sequence with coarser tempestite interbeds. Mineralogically and texturally graded accumulations of phenocrysts mark the bases of the thickest tephra beds. Early diagenetic concretions in one composite tephra preserve precompaction fabrics and original hypocrystalline textures with microphenocrysts and devitrified glass shards. The presence of plagioclase, quartz, K-feldspar, biotite, apatite, and zircon suggest a rhyolitic source. The coarseness of the microphenocrysts in the basal accumulations, along with the abundance and thickness of the tephras, suggest that deposition in the Gaspe area was in a proximal position relative to the volcanic source. The zonal graptolites Monograptus praehercynicus and Monograptus aequabilis ssp. from the Petit Portage Member indicate a middle Lochkovian age for the Lac au Renard Tephra Cluster of the Indian Point Formation. Correlation with the tephra cluster that includes the Judds Falls Bentonite in the New Scotland Formation and other possible tephras in the Kalkberg Formation (Helderberg Group) of New York and the Corriganville and Mandata formations of Pennsylvania is likely. The graptolite fauna of the Indian Point and probable correlations to New York may provide additional biostratigraphic constraints on a $\mathrm{U}-\mathrm{Pb}$ zircon radiometric age determination of $417.6 \mathrm{Ma}$ from $\mathrm{New}$ York that has been used to estimate the age of the Silurian-Devonian boundary.
\end{abstract}

\section{RÉSUMÉ}

Une vingtaine d'amoncellements de téphras, dont l'amas de téphras du lac au Renard (nouvel amas), sont présents dans les membres de l'anse Rosebush et de Petit Portage de la Formation d'Indian Point (groupe de Chaleurs) en Gaspésie, au Québec, Canada. Les strates de téphras, dont l'épaisseur varie entre $<1,0 \mathrm{~cm}$ et $82 \mathrm{~cm}$, se manifestent dans une séquence à prédominance de pélite interlitée de tempestite plus grossière. Des accumulations de phénocristaux dont la composition minéralogique et la texture varient progressivement marquent les bases des strates les plus épaisses de téphras. Des concrétions diagénétiques précoces dans un amas de téphras composite préservent les fabriques préalables à la compaction et les textures hémicristallines originales en compagnie de microphénocristaux et d'éclats de verre dévitrifiés. La présence de plagioclase, de quartz, de feldspath potassique, de biotite, d'apatite et de zircon laisse supposer une source rhyolitique. La grossièreté des microphénocristaux dans les accumulations basales de même que l'abondance et l'épaisseur des amas de téphras permettent de supposer que le dépôt des téphras en Gaspésie est survenu à proximité d'une source volcanique. Les graptolites zonaux - sousespèces Monograptus praehercynicus et Monograptus aequabilis - du membre de Petit Portage confèrent à l'amas de téphras du lac au Renard de la Formation d'Indian Point un âge le situant au Lochkovien moyen. Il est probable qu'il puisse être corrélé à l'amas de téphras englobant la bentonite des chutes Judds dans la Formation de New Scotland et d'autres téphras possibles dans la Formation de Kalkberg (groupe de Helderberg) de New York ainsi que les formations de Corriganville et de Mandata en Pennsylvanie. La faune de graptolites d'Indian Point et les corrélations probables avec New York pourraient imposer d'autres contraintes biostratigraphiques à la datation radiométrique $\mathrm{U}-\mathrm{Pb}$ sur zircon de 417,6 Ma obtenue de New York qui a servi à l'estimation de l'âge de la limite siluro-dévonienne.

[Traduit par la redaction] 


\section{INTRODUCTION}

Some altered volcanic tephras (also known as K-bentonites) are significant event-stratigraphic markers because they are deposited synchronously over large areas and across a broad spectrum of depositional environments. However, even when they exhibit more complex depositional histories (Ver Straeten 2004a, 2008), such tephras may still serve as significant stratigraphic markers. Tephras commonly include minerals such as zircon and monazite that contain radiogenic isotopes that enable the determination of radiometric ages. Important opportunities for calibration of the geologic time scale are presented where tephras occur in strata that contain index fossils (e.g., Tucker et al. 1998; McAdams et al. 2017).

This paper expands on a preliminary report (Ebert et al. 1997) of a suite of tephras (herein named the Lac au Renard Tephra Cluster) from the Rosebush Cove and Petit Portage members of the Indian Point Formation, Chaleurs Group (Fig. 1) on the Gaspe Peninsula (Gaspesie) of Quebec, Canada (Fig. 2). Because zonal monograptids occur in the same strata, the Lac au Renard Tephra Cluster offers great potential for refining Lower Devonian time-scale calibration.

\section{PREVIOUS WORK}

The middle Paleozoic stratigraphy of Gaspesie was first described in the pioneering works of Sir William Logan $(1845,1846,1863)$, who divided the section into eight units. Several schemes of stratigraphic nomenclature (e.g., Russell 1946/1976; Cumming 1959; Burk 1964; Bourque 1975, 1977) followed Logan's original descriptions and applied geographic names to the units. Bourque (1975) standardized the nomenclature and his scheme is followed here (Fig. 1).

Lithologic descriptions, accurate thicknesses, and the roots of the modern stratigraphic nomenclature for the Silurian-Devonian units of Gaspe were presented by Russell (1946) in an unpublished but widely cited manuscript. Russell's work was formally published in 1976 and will be referenced throughout with the later date. Cumming (1959) summarized the pre-1959 work on the area, which comprised numerous mapping projects (e.g., McGerrigle 1950) and largely adopted the descriptions of Logan and Russell. However, Cumming $(1959$, p. 19) was the first to report monograptids from the Petit Portage Member of the then-termed Cap Bon Ami Formation (now regarded as a member of the Indian Point Formation). He misidentified these graptolites as Monograptus uncinatus var. micropoma and the strata bearing them were, therefore, interpreted as Silurian. Burk (1964) accepted the Silurian interpretation, which was disputed by Boucot (1965) and Berry (1965) (See also reply by Burk 1965.). Boucot et al. (1967) redescribed Cumming's monograptids and identified them as Monograptus aequabilis, thereby re-assigning the beds that contained them to the Lower Devonian. Achab and Asselin (1993) reported chitinozoans from the base of the Rosebush
Cove Member and from the top of the Petit Portage Member. These chitinozoans were characterized as Pridolian, although they included some Lochkovian elements.

Cumming (1959, p. 16, his fig. 4) also illustrated, but did not describe, a "thin bentonite bed" in close proximity to his "monograptus beds" from the type locality of the Petit Portage Member at Cap des Rosiers Cove. Bourque et al. (1995, p. 337) reported that "volcanic rocks are absent in the northern sequence", although they were referring specifically to lava flows, which are present in Silurian strata south of the present study area.

Bourque (1977) and Brisebois (1981) provide the most recent geologic maps of the study area. Their mapping facilitated assignment of the units bearing the tephras to members of the Indian Point Formation (equivalent to parts of the St. Alban, Cap Bon Ami and St. Leon formations of the older literature). The Indian Point Formation is correlated to the west with part of the St. Leon Formation (e.g., Lavoie 1992). Ebert et al. (1997) reported the occurrence of multiple K-bentonites in the Indian Point Formation (Fig. 1) that are the subject of this paper.

\section{LOCATION}

The study area is located in eastern Quebec near the village of Rivière Morris in the northeastern portion of Gaspe (Fig. 2). The Lac au Renard Tephra Cluster (Fig. 3) is well exposed in an extensive road cut on Rt. 197, which parallels the western boundary of Forillon National Park. The outcrop is outside the park boundary on the western side of the road.

\section{METHODS}

The tephra beds in the Rt. 197 road cut were discovered during reconnaissance field work. Preliminary samples were collected and examined. The section was later measured and described. The thickest tephras that were identified in the reconnaissance work were re-sampled, along with thinner tephras or beds suspected to be tephras. Accumulations of phenocrysts at the bases of some of the thickest tephras and portions of concretions from an interval with multiple, thin tephras were sampled. Thin sections were prepared from these samples. The graptolite-bearing interval was discovered during the course of measuring the section and specimens were collected for further study.

Samples of tephra and suspected tephra were emulsified in a blender with water and sodium hexametaphosphate (Calgon). Emulsified samples were then wet sieved to remove clays and coarse components $(>0.71 \mathrm{~mm}$, i.e., coarse sand). The sieve stack comprised the $0.71 \mathrm{~mm}, 0.074 \mathrm{~mm}$ and $0.045 \mathrm{~mm}$ sieves. The $0.074 \mathrm{~mm}$ and $0.045 \mathrm{~mm}$ fractions were dried and kept for examination.

Dense minerals were separated from the $0.074 \mathrm{~mm}$ fraction using the non-toxic heavy liquid lithium metatungstate 


\begin{tabular}{|c|c|c|c|c|}
\hline \multirow{11}{*}{ 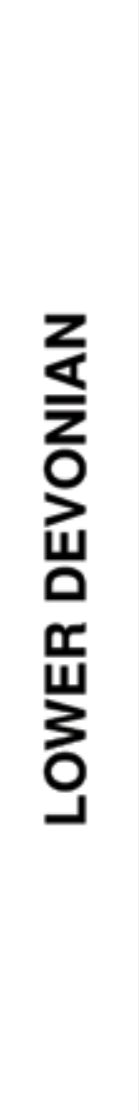 } & STAGE & GROUP & FORMATION & MEMBER \\
\hline & \multirow{3}{*}{$\begin{array}{l}z \\
\sum_{\text {W }}^{\mathbf{L}}\end{array}$} & \multirow{2}{*}{ 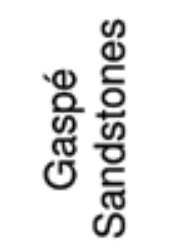 } & Battery Point & \\
\hline & & & York River & \\
\hline & & \multirow{4}{*}{ 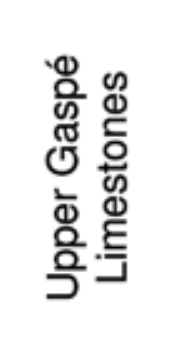 } & Indian Cove & \\
\hline & \multirow{3}{*}{ 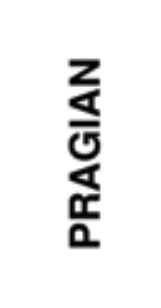 } & & Shiphead & \\
\hline & & & & Cap Gaspé \\
\hline & & & 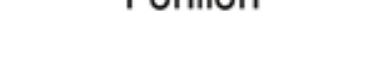 & Mont Saint-Alban \\
\hline & & & 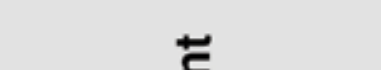 & Cape Road \\
\hline & 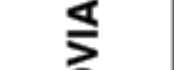 & & 움 & Quay Rock \\
\hline & 空 & & 듬 & Petit Portage \\
\hline & త్త & 党 & & Rosebush Cove \\
\hline & & ড় & Roncelles & \\
\hline 嵓孚 & 음 & & West Point & \\
\hline$\supset \overline{\bar{\circlearrowleft}}$ & $\overline{\mathbf{\alpha}}$ & & Griffon Cove River & \\
\hline
\end{tabular}

Figure 1. Stratigraphic nomenclature for the northern outcrop belt of the Gaspe Peninsula after Bourque (1975) and Lavoie (1992). Units discussed in this paper are shaded.

at densities ranging between 2.7 and $3.1 \mathrm{~g} / \mathrm{cm}^{3}$. Dense separates were washed with water and the diluted lithium metatungstate was reclaimed by evaporation. Examination under a dissecting microscope confirmed preliminary identification of tephras by revealing the presence of euhedral microphenocrysts (e.g., Fig. 3). For some samples, the $0.045 \mathrm{~mm}$ fraction was also separated and examined.

Graptolite samples were cleaned and studied under a dissecting microscope. Where preserved, the proximal rhabdosome, including the sicula and first two thecae, was studied for specific identification.

\section{LITHOSTRATIGRAPHY OF THE LAC AU RENARD TEPHRA CLUSTER}

Bourque (1977) mapped the exposure on Route 197 as a part of the Indian Point Formation, a subdivision of the Silurian-Devonian (Pridolian-Lochkovian) Chaleurs Group (Fig. 2). The Indian Point Formation is subdivided into four members in eastern Gaspe. In ascending order, these are Rosebush Cove, Petit Portage, Quay Rock and Cape Road (Fig. 1). The Rosebush Cove and Petit Portage members are well exposed in the Route 197 road cut. These members contain the Lac au Renard Tephra Cluster, named after Lac au Renard (Fox Lake, also known as Lac de la Montagne du Roche/Rock Mountain Lake), a small lake to the east of the outcrop in Forillon National Park. Clusters of tephra beds are characteristic of the middle Paleozoic of the northern 


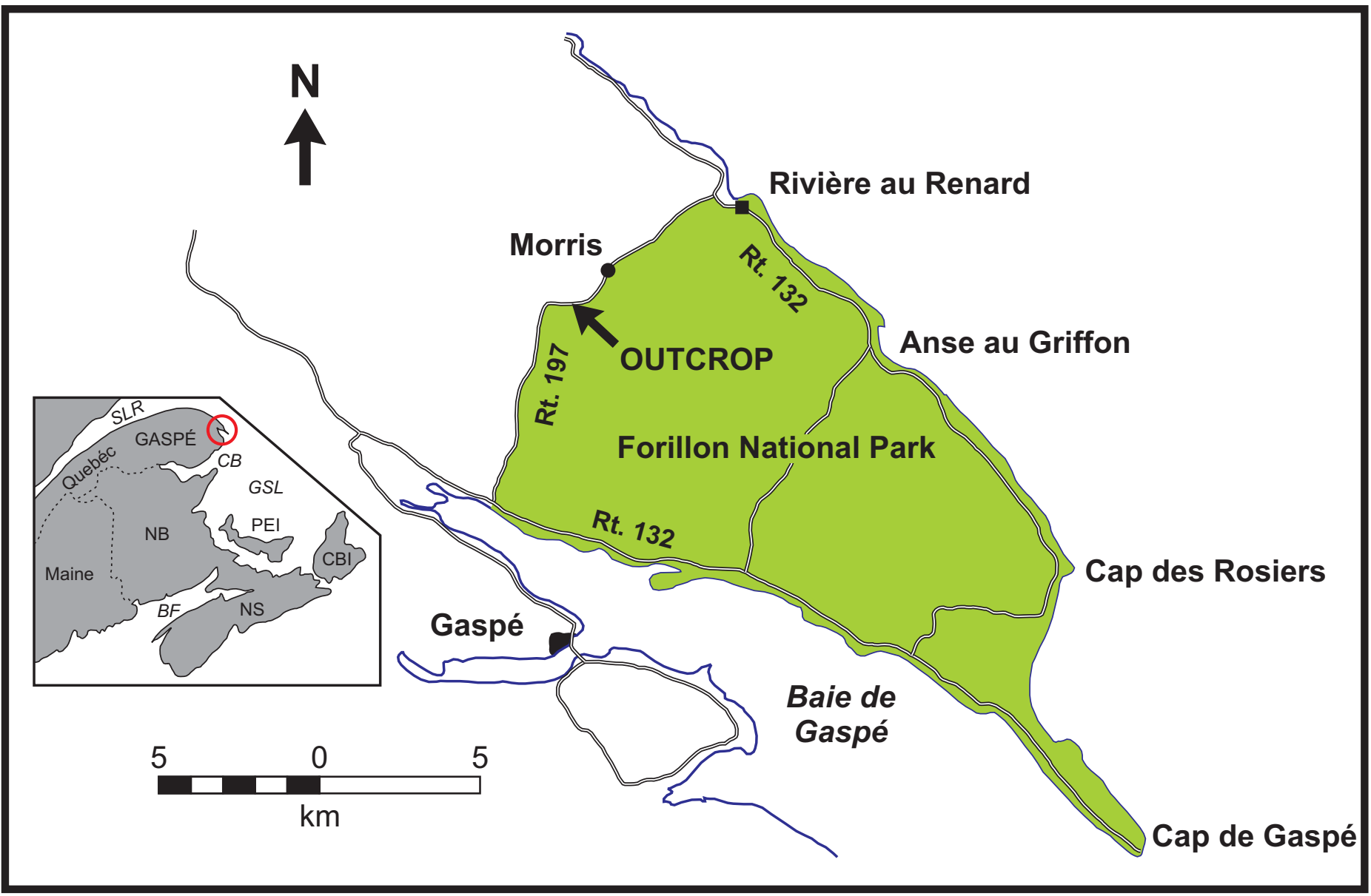

Figure 2. Location map for measured section of the Rosebush Cove and Petit Portage members of the Indian Point Formation and type section for the Lac au Renard Tephra Cluster (new) on Route 197 along the western boundary of Forillon National Park. The type section for various members of the Indian Point Formation is located on the coast, just south of Cap des Rosiers. Inset map shows location of study area (red circle) on the Gaspe Peninsula, Quebec, Canada. BF = Bay of Fundy, CB = Chaleurs Bay, CBI = Cape Breton Island, GSL = Gulf of St. Lawrence, NB = New Brunswick, NS = Nova Scotia, PEI = Prince Edward Island, SLR = St. Lawrence River.

Appalachian Basin (e.g., New York and Pennsylvania; Ver Straeten 2004a, b and Ver Straeten et al. 2005). Although the thickest tephra (A on Fig. 4 and Fig. 5) occurs in the Rosebush Cove Member, the tephra beds occur and are represented roughly equally in the two members.

The upper members of Indian Point Formation crop out sporadically to the south of the studied section. Portions of the Pragian Upper Gaspe Limestone, including the Shiphead Formation, which also contains tephra beds (see Smith 1967 and Smith et al. 1961), are exposed farther south along Route 197.

Nearly $90 \mathrm{~m}$ of the Rosebush Cove Member and more than $90 \mathrm{~m}$ of the Petit Portage Member are exposed in the studied road cut (Fig 4). These members comprise red, green and grey mudstone, shale, and siltstone, with less common fine sandstone, rare limestone, and tephra. Red to maroon coloration is most prevalent in the Rosebush Cove Member, but red intervals also occur in the lower parts of the Petit Portage Member.

Although commonly referred to as a carbonate sequence, the Indian Point Formation is dominated by siliciclastic rocks (Fig. 4). Shale, mudstone, and siltstone make up more than $90 \%$ of the thickness of the Route 197 section. Coarse siltstone, fine sandstone, limestone, and tephra make up the remainder of the section. Fine-grained strata vary from well-laminated shale to mudstone with nearly homogeneous internal structure. Homogeneous mudstone predominates and typically exhibits crumbly fracture. Less commonly, pencil cleavage is expressed.

Ball and pillow structures and flame structures appear in many of the mudstone-dominated intervals. In addition to these features of soft-sediment deformation, metre-scale, wedge-shaped to listric truncation surfaces are also present. These surfaces are probably the result of minor failure of semi-consolidated mud on the depositional slope. Bishuk et al. (1991) reported similar features from superficially similar facies in the Catskill Clastic Wedge in New York. Geometrically similar, but much larger, truncations were reported by Davies (1977).

Coarser siltstone, very fine sandstone, and rare skeletal 


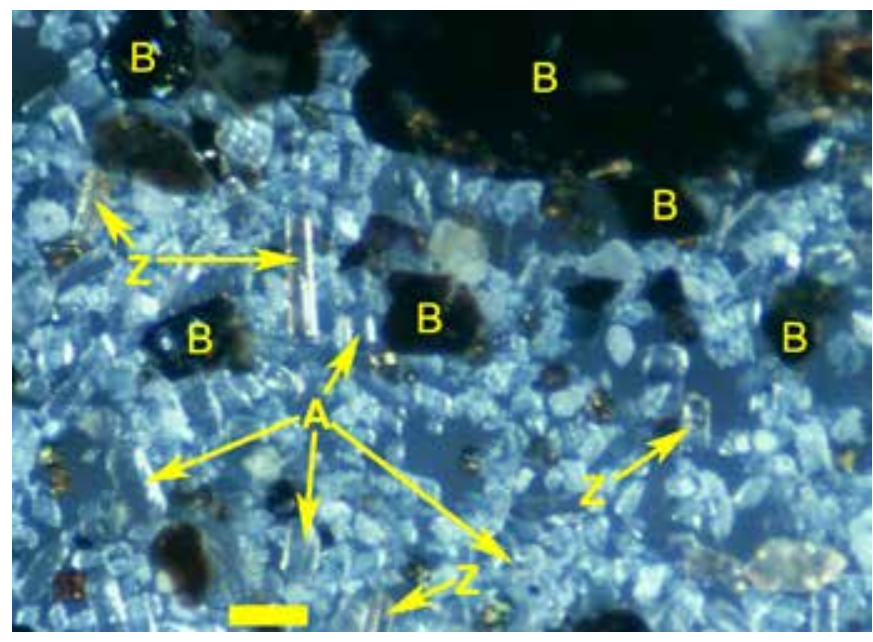

Figure 3. Example of heavy mineral separates from Tephra B. Scale bar is approximately $0.1 \mathrm{~mm} . \mathrm{Z}=$ zircon, $\mathrm{A}=\mathrm{ap}$ atite, $\mathrm{B}=$ biotite.

grainstone beds bear subtle sedimentary structures. Lowangle $\left(<10^{\circ}\right)$ inclined laminations and low-angle truncation surfaces, reminiscent of hummocky cross-stratification, are visible in some beds (Fig. 6). The bases of such beds are sharp. Tops are sharp or gradational into overlying mudstone. Low-relief, crudely symmetrical ripples (amplitudes less than $1 \mathrm{~cm}$ ) are present at the tops of some beds (Fig. 6).

The combination of sharp erosional bases, crude grading, low-angle lamination, and rippled tops suggests a tempestite origin for the coarser beds in the Indian Point Formation. Common features of soft-sediment deformation and low-angle truncation surfaces indicate rapid deposition and some slope to the depositional surface. Bourque et al. (1986) suggested a deltaic origin for the lower members of the Indian Point Formation. Bourque et al. (1995) described the Petit Portage Member as "turbiditic". Our observations do not preclude a deltaic interpretation. However, we interpret the coarser beds of the lower members of the Indian Point as tempestites, rather than turbidites.

\section{PETROLOGY OF THE LAC AU RENARD TEPHRA BEDS}

The tephra beds of the Lac au Renard Tephra Cluster in the Indian Point Formation range between fairly competent claystone to highly weathered zones of clay. Both are easily distinguished in the field from the more common nonpyroclastic mudstone and shale of the Rosebush Cove and Petit Portage members of the Indian Point Formation. The tephra weathers to pale green, greenish white, or white, which contrasts sharply with the surrounding relatively drab mudrock, sandstone, and limestone (Fig. 5). Tephra beds in the Lac au Renard Tephra Cluster range in thickness from less than $1.0 \mathrm{~cm}$ to $82.0 \mathrm{~cm}$ (Figs. 4 and 5).

The bedding surface that underlies one of the tephra beds preserves a detailed microtopography, comprising burrows and trails (Fig. 7). Vertical "rampart and moat" burrows show little compaction and no evidence of erosional scour around them. Cruziana-like trails are also well-preserved. These features argue for rapid deposition for at least one of the Lac au Renard tephra beds in the Petit Portage Member.

Textural features and mineralogy also support the interpretation of rapid emplacement. At the bases of several of the thicker tephra beds, well-developed (up to a centimetre thick) accumulations of anhedral to euhedral phenocrysts occur (Fig. 8). Grading is visible in some accumulations. Phenocrysts (averaging $0.5 \mathrm{~mm}$, but up to $1.0 \mathrm{~mm}$ diameter) are predominantly feldspars (plagioclase and K-feldspar) and quartz. However, in the field, biotite $(1.0-1.5 \mathrm{~mm}$ diameter) is the most visible component, as it is concentrated in the upper portions of the graded accumulations. Bedding-plane exposures may display a schist-like appearance because of the abundance of biotite flakes (Fig. 9). This textural and compositional grading suggests that each thick tephra was deposited from suspension as a single, shortlived event. However, more complex depositional histories, such as those described by Ver Straeten (2004a, 2008) may be possible for some of the Lac au Renard tephras. This is particularly true for the interval designated as D in Figures 4 and 10 and possibly for the very thick A tephra $(82 \mathrm{~cm})$. The concretion-bearing interval $\mathrm{D}$ comprises multiple interbeds of shale, claystone, and siltstone; the latter two are likely pyroclastic in origin. The $\mathrm{D}$ interval comprises multiple tephra beds in close succession.

The coarser portions of the graded intervals display anhedral to subhedral grains of feldspars and quartz, with lesser quantities of biotite (Fig. 8). Rare crystals of apatite and zircon (both typically euhedral; e.g., Fig. 3) are also present but are more common in the finer portions of the graded intervals. Biotite is present throughout the accumulations of phenocrysts, but is most common at the tops of the graded intervals. Phenocrysts are partly surrounded by a fine silt- to clay-size matrix, which may have been glass shards originally (see below).

Plagioclase crystals commonly display albite and Carlsbad twinning. Most are quite fresh in appearance with only minor alteration to sericite. Anorthite content was estimated by extinction angle in several thin sections from the phenocryst-rich zone at the base of the B tephra (Fig. 4). Mean calcium content is estimated at approximately An 40 or andesine $(\mathrm{n}=18)$, though this average does not take zoning into account. Other samples did not contain sufficient numbers of grains to merit measurements of extinction angles.

The combination of plagioclase, quartz, and K-feldspar, with abundant biotite and less common apatite and zircon, indicate a rhyolitic magma source, which is consistent with the pyroclastic origin of Lac au Renard tephras.

Calcareous concretions, ranging from approximately 4 to $25 \mathrm{~cm}$ in the bedding-parallel direction, are present in the $\mathrm{D}$ tephra interval, which is actually a thick sequence of thinner tephras interbedded with coarser lithologies (Fig 4; Fig. 10). Thin sections from these concretions reveal excellent 


\section{Indian Point Formation Rt. 197 near Forillon National Park}
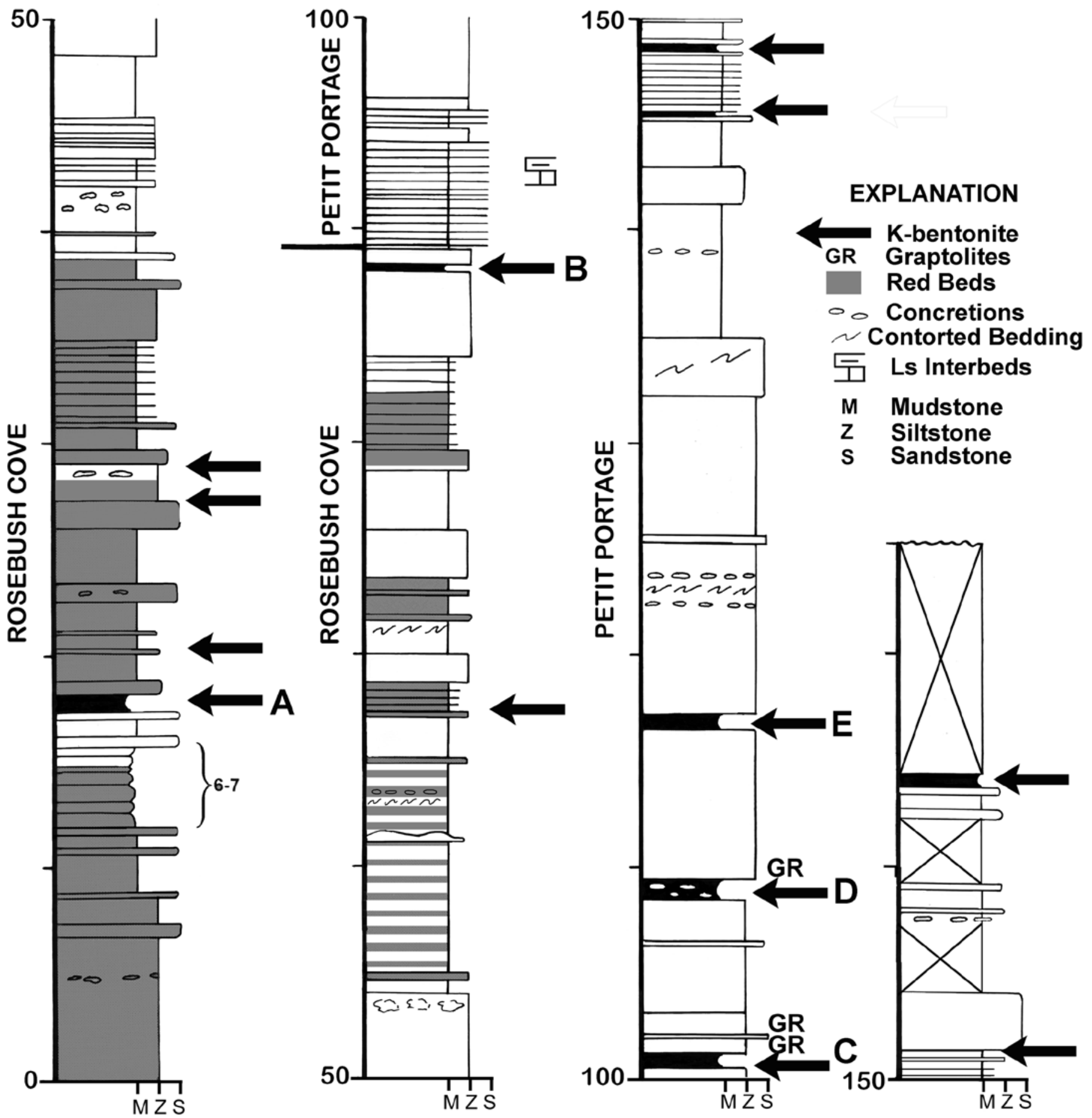

Figure 4. Measured section of exposed portions of the Rosebush Cove and Petit Portage members of the Indian Point Formation in the road cut on Rt. 197, southwest of Morris and at the boundary of Forillon National Park. Arrows indicate the position of tephras of the Lac au Renard Tephra Cluster. The thickest tephras are designated with letters A-E. The bracketed interval labeled 6-7 indicates a zone of 6 to 7 thin tephras. GR = graptolite-bearing beds. It is possible that the upper portion of the section, beginning at the 135-metre mark may be assigned to the Quay Rock Member of the Indian Point Formation. If this is the case, then the Lac au Renard Tephra Cluster extends through most of the Indian Point Formation. 


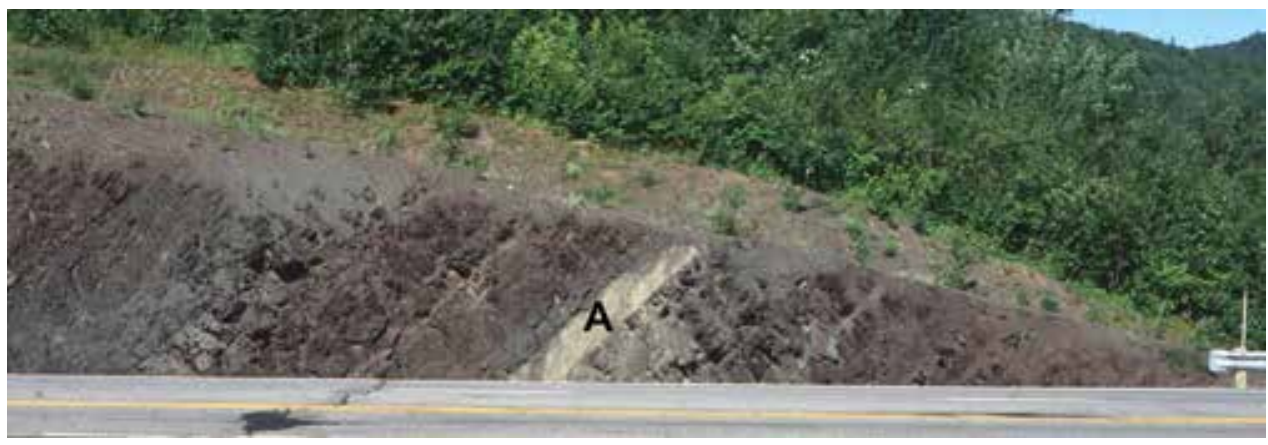

Figure 5. Mudstone beds of the Rosebush Cove Member of the Indian Point Formation (Chaleurs Group) and tephra A. At $82 \mathrm{~cm}$ thick, tephra A is the thickest of the tephras in the Lac au Renard Tephra Cluster.

preservation of the original fabric of the ash, with only minor compaction (Fig. 11). Large volumes (>50\%) of coarse, equant calcite cement prevented significant compaction and minimized destruction of original pyroclastic textures. Minor compaction is indicated by a crude, bedding-parallel alignment of planar grains. The volume of cement and comparison of concretion thickness with laterally equivalent, compacted tephra beds imply that the Lac au Renard tephras were probably at least twice their present thickness when they were deposited. Thin sections from the concretions were etched in dilute hydrochloric acid prior to photographing to eliminate the visual distraction of the cementing crystals so that the pyroclastic features could be seen more clearly.

Devitrified glass shards, with long dimensions averaging $0.15 \mathrm{~mm}$, make up the bulk of the original tephra (Fig. 11). Small crystals of feldspar, quartz, and other minerals are visible in individual shards under high magnification (400×). Some shards exhibit the characteristic Y-shape of glass (Fig. 11) that formerly surrounded gas-filled voids. An originally hypocrystalline texture is evident by the presence of fragments and whole microphenocrysts of feldspars, quartz, biotite, and rare apatite and zircon among the shards. These microphenocrysts and fragments are smaller (average long dimension $0.12 \mathrm{~mm}$ ) than those of the associated graded accumulation from the base of the bed (range from 0.2 to $0.6 \mathrm{~mm}$ ). The vertical size grading of phenocrysts and fragments records settling from suspension. There is no appreciable difference in size between the glass shards and the associated phenocrysts and fragments, so hydraulic equivalence is not demonstrated. However, the crude alignment of biotite phenocrysts and shards parallel to bedding indicates some compaction has occurred which could have crushed pumiceous lumps that were originally larger and may have been hydraulically equivalent to the smaller microphenocrysts and fragments.

\section{BIOSTRATIGRAPHY AND THE AGE OF THE LAC AU RENARD TEPHRA CLUSTER}

Cumming (1959) reported the occurrence of a thin interval in the Petit Portage Member that yielded monograptids from the type section of the member and from an outcrop in the area of Rivière au Renard, which is near the area of the present study. Cumming (1959, p.19) identified these as Monograptus uncinatus var. micropoma and assigned the Petit Portage to the Silurian. Boucot et al. (1967) later

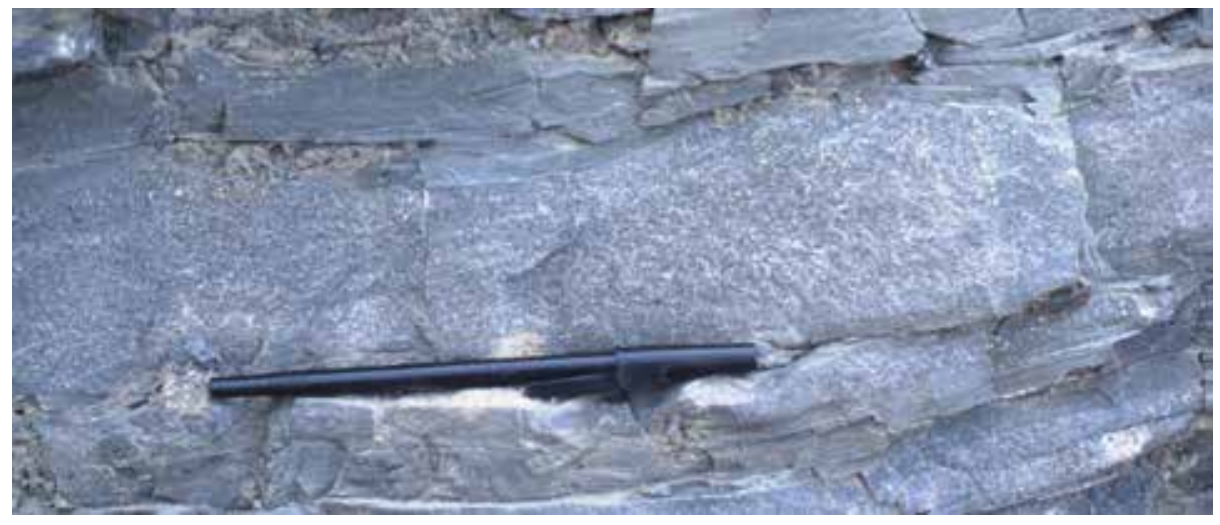

Figure 6. Ripples or small-scale hummocky cross-stratification in one of the coarser, limestone beds (skeletal grainstone) in the Petit Portage Member. The geometry of the ripples and the form-concordant stratification indicate that the bed was deposited under oscillatory to combined flow conditions. 


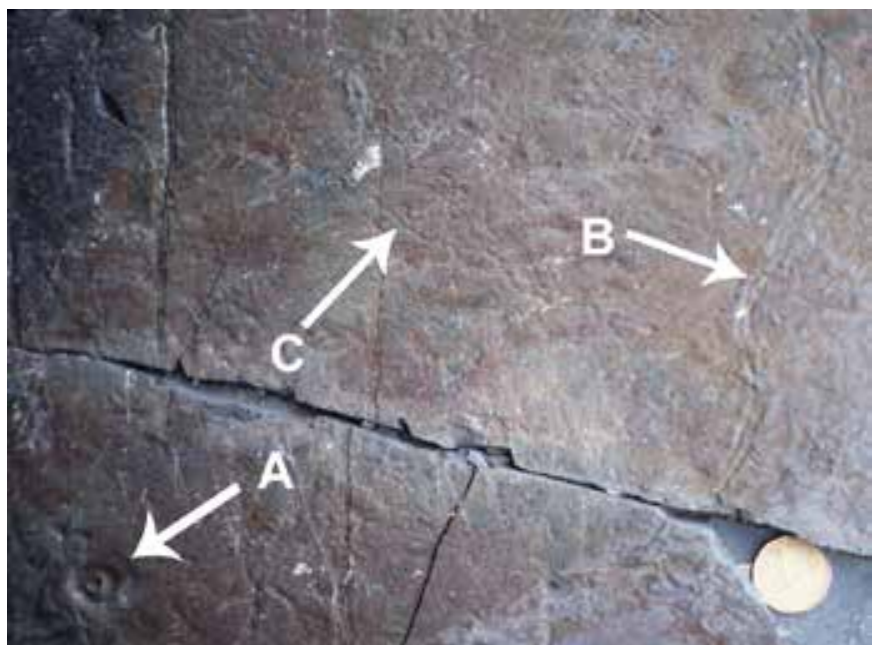

Figure 7. Microtopography on the bedding plane upon which tephra $\mathrm{C}$ was deposited. A vertical burrow (A) displaying "rampart and moat" form, a Cruziana trail (B) and a single, worm-like trace (C) on the top of the bed below tephra $\mathrm{C}$ are well preserved. These features indicate a lack of erosion and/or hiatus-related sedimentary condensation prior to the deposition of tephra C. Burial and preservation of such fine, delicate features argue for rapid, single-event emplacement of tephra C. A Canadian dollar coin provides scale.

re-described these monograptids as Monograptus aequabilis, indicating a Lower Devonian age.

New samples were collected from Cumming's "Monograptus beds" exposed along Route 197 (Fig. 10). Although the monograptids are compressed and show slight tectonic stretching, they are quite identifiable. Most specimens are assignable to Monograptus aequabilis ssp. (Fig. 12), as previously reported by Boucot et al. (1967). In addition to Monograptus aequabilis ssp., Monograptus praehercynicus (Fig. 12) occurs in the same beds. The presence of Monograptus praehercynicus restricts the age of this part of the Petit Portage Member to the middle Lochkovian praehercynicus zone. Monograptus aequabilis ssp. alone is sufficient for assignment to the Lower Devonian (Lochkovian to Pragian). However, this species is rather long ranging in comparison to Monograptus praehercynicus (e.g., see Chlupač et al. 1985). The concurrent range zone of Monograptus aequabilis ssp. and Monograptus praehercynicus represents a relatively small fraction of the range of Monograptus praehercynicus, near the boundary with the subjacent uniformis zone, and indicates the possibility of very precise correlations to other graptolite-bearing sequences. Lenz (1972) reported Monograptus praehercynicus from the St. Leon Formation in the area near Murdochville, approximately $75 \mathrm{~km}$ west of the present study area. Much of the St. Leon Formation is correlative with the Indian Point Formation of eastern Gaspesie (Bourque 1977; Brisebois 1981). All of the available graptolite data supports assignment of Indian Point strata to the Lochkovian Stage (Lower Devonian) (See also Jaeger 1979).

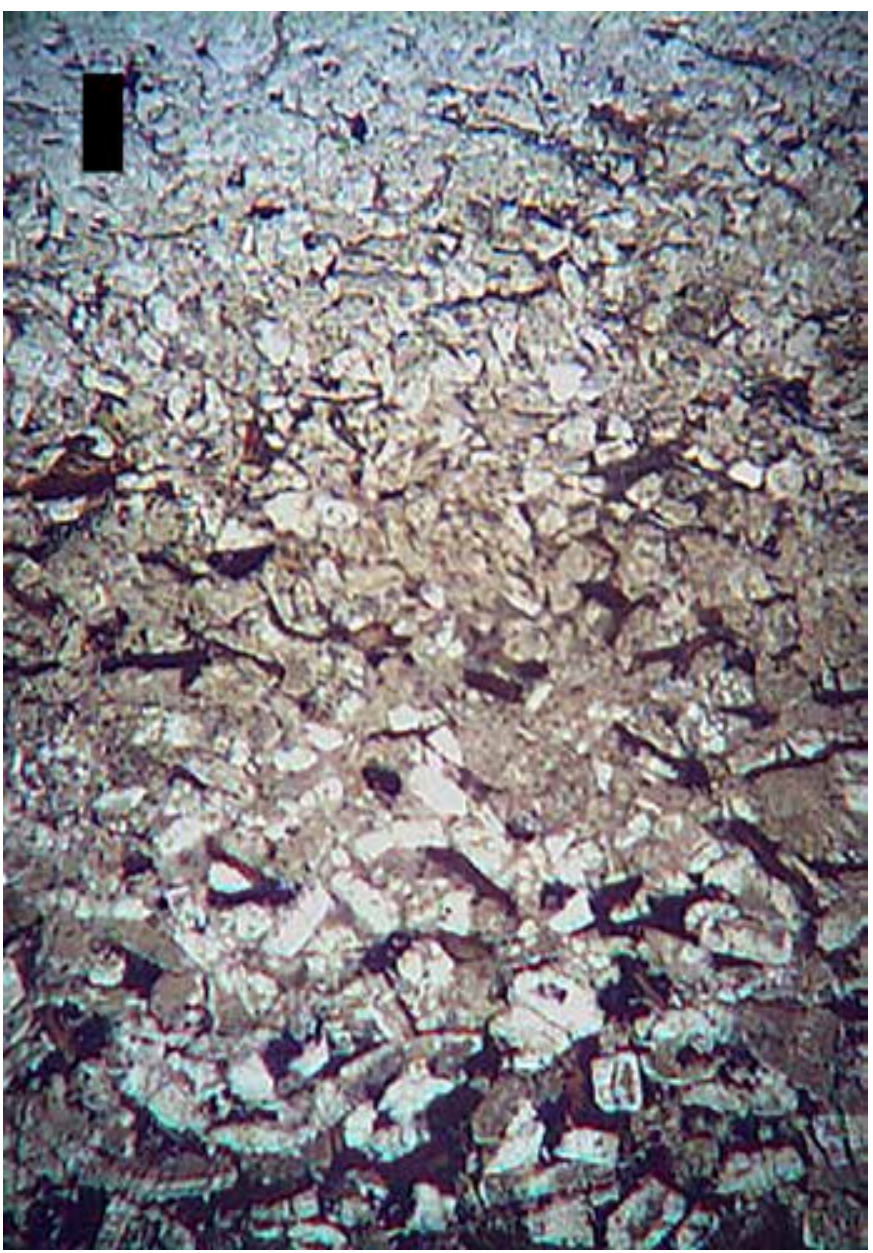

Figure 8. Photomicrograph of graded accumulation of phenocrysts at the base of tephra B. Phenocrysts are dominated by plagioclase, K-feldspar and quartz. Biotite occurs throughout but becomes more common at the top of the graded interval. Scale bar is approximately $1.0 \mathrm{~mm}$.

Bourque (1977) assigned the Indian Point Formation to the Lower Devonian on the basis of the brachiopod fauna (e.g., Anoplia pygmaea, Coelospira virgiana) from the Rosebush Cove Member.

Achab and Asselin (1993) described chitinozoans from portions of the Indian Point Formation outcrop on Route 197. From the base of the Rosebush Cove Member, they reported Muscochitina aff. M. mucosa, Ancyrochitina aff. A. desmea, Urnochitina urna, Cingulochitina ervensis, and a new form of Desmochitinidae. Upper beds of the Petit Portage Member yielded Cingulochitina serrata, Linochitina klonkensis, Margachitina catenaria catenaria, Urnochitina urna, Gotlandochitina sp.1, Pterochitina sp. and, Calpichitina $s p$. (Achab and Asselin 1993). From these associations, Achab and Asselin (1993) ascribed a Pridoli age to the Rosebush Cove and Petit Portage members of the Indian Point Formation. However, Muscochitina aff. M. mucosa is restricted to the Lochkovian (Paris 1981a, b; Paris et al. 1981, 2000). Ancyrochitina aff. A. desmea has been renamed Ancyrochitina morzadeci, which occurs in the upper Emsian 


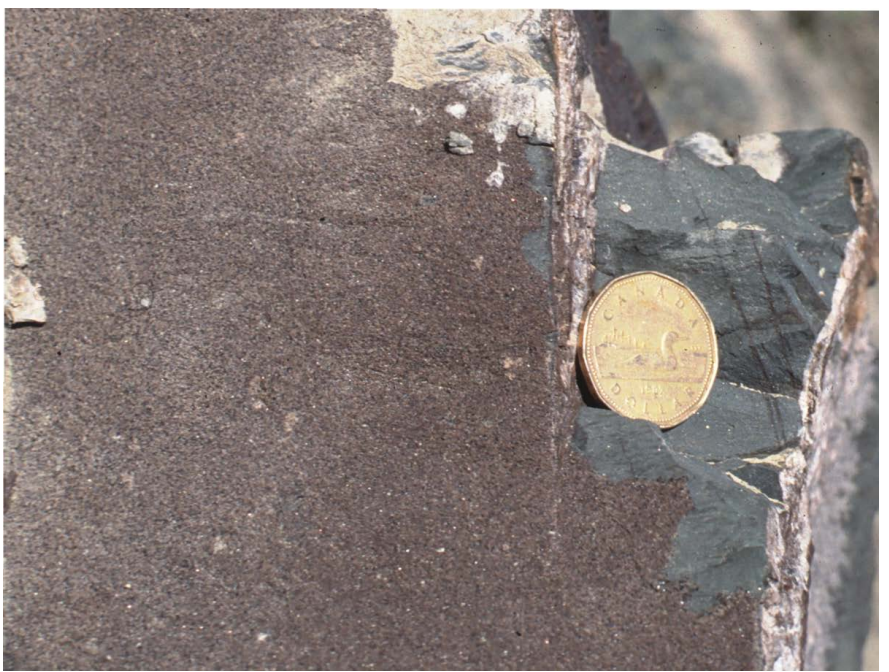

Figure 9. Bedding plane of sample found in float. This surface apparently occurs near the base of one of the Lac au Renard tephras. The surface is covered by biotite phenocrysts which give a schist-like appearance in the field. Canadian dollar coin for scale.

(Paris 1981a, b; Paris et al. 2000). The Pridolian index species Urnochitina urna has been shown to range into the lowest Lochkovian (Paris 1981a, b; Paris et al. 2000; Verniers, et al. 1995). Chlupač et al. (1985) also noted that the uppermost Lochkovian form, Urnochitina sp. A is strikingly similar to Urnochitina urna, which raises the possibility that this is actually the species present in the Indian Point Formation. Cingulo-chitina ervensis and Cingulochitina serrata range from the Pridolian through the Lochkovian, but do not extend into the Pragian (Paris 1981a. b; Paris 2000; Chlupač et al. 1985). Margachitina catenaria catenaria extends from lower Lochkovian into the lowest Pragian (Chlupač et al. 1985). Species of Gotlandochitina typically range from upper Lochkovian to upper Emsian (Paris 1981a, b; Paris et al. 2000). Without designation of species, the genera Desmochitina, Calpichiti$n a$ and Pterochitina cannot be assigned to a specific stage.

Most of the chitinozoans reported by Achab and Asselin (1993) are either typical of the Lochkovian, range from the Pridolian into the Lochkovian, or are Lochkovian and younger. Only Linochitina klonkensis has not been shown to range above the Silurian-Devonian boundary. The occurrence of Linochitina klonkensis with typically Lochkovian and younger species suggests that its range may extend higher in Gaspe than in the Barrandian type area. Alternatively, Linochitina klonkensis may have been reworked into the Lochkovian beds of the Petit Portage Member.

In summary, multiple species of graptolites (this paper; Boucot et al. 1967; Lenz 1972), brachiopods (Bourque 1977), and chitinozoans (Achab and Asselin 1993, reinterpreted herein) firmly demonstrate the Lochkovian age of the Lac au Renard Tephra Cluster in the lower members of the Indian Point Formation.

\section{CORRELATION OF THE LAC AU RENARD TEPHRAS AND LINKS TO POSSIBLE VOLCANIC SOURCES}

Tephra beds similar in age to the Lac Au Renard cluster have been reported from the Appalachian Basin. Rickard $(1962,1975)$ reported a single, volcanic ash bed from the Kalkberg Formation at Cherry Valley, New York, in the Upper Silurian to Lower Devonian Helderberg Group. Ebert et al. (2007) reinterpreted these strata at Cherry Valley as part of the New Scotland Formation. Conkin and Conkin (1984) named this tephra the Judds Falls Metabentonite. Smith et al. (1988) identified three K-bentonites, which they christened the "Bald Hill Bentonites", in the Lower Devonian Corriganville Limestone and Mandata Shale of Pennsylvania. Correlation from Pennsylvania to Cherry Valley, New York, suggested that the lowest of their Bald Hill Bentonites (Bald Hill A) corresponds to the tephra that Rickard originally reported (Smith et al. 1988). The name Judds Falls Metabentonite (Conkin and Conkin 1984; amended to Judds Falls Bentonite by McAdams et al. 2017), has precedence over the Bald Hill designation of Smith et al. (1988) for Rickard's original tephra (Bald Hill A of Smith et al. 1988) at Cherry Valley. Shaw et al. (1991) identified $5 \mathrm{~K}$-bentonites in a large road cut on I-88 near Schoharie, New York from strata that they called Kalkberg Formation. Ebert et al. (1992) subsequently reported 7 tephra beds from I-88 and 6 at Cherry Valley in strata later identified as the New Scotland Formation (Ebert et al. 1997). Hanson et al. (1992a, b) and Hanson (1995) reported 8 K-bentonites at Cherry Valley and 6 at I-88. Through geochemical fingerprinting of melt inclusions in quartz phenocrysts, Hanson (1995) demonstrated that the tephra called Bald Hill A is actually two chemically distinct tephras at different localities and that Smith et al. (1988) miscorrelated their Bald Hill C bed to Cherry Valley. Husson et al. (2015) presented U-Pb zircon ages from Rickard's original tephra at Cherry Valley and for 4 tephras at I-88.

Milunich and Ebert (1993) suggested the possibility of time-scale calibration from the Cherry Valley and Schoharie occurrences. Subsequently, this calibration was accomplished (Tucker et al. 1998; Kaufmann 2006). Rickard's tephra (Judds Falls Bentonite) has yielded U-Pb zircon ages of 417.6 $\pm \mathrm{Ma}$ (Tucker et al. 1998), $417.68 \pm 0.52 \mathrm{Ma}$, (Husson et al. 2015), and 417.6 $\pm 0.50 \mathrm{Ma}$ (McAdams et al. 2017).

As early as 1910, beds that are now referred to as Indian Point Formation were correlated with the "basal New Scotland" of New York (see Russell 1976). On the basis of brachiopod biostratigraphy, Johnson and Murphy (1969) showed that the New Scotland Formation in New York could be assigned to the praehercynicus zone. Bevington et al. (2010) and McAdams et al. (2017) reported the chitinozoans Eisenackitina bohemica, Margachitina catenaria, Pterochitina megavelata, and Cingulochitina ervensis indicating a middle Lochkovian age for the tephra-bearing portion of the New Scotland Formation at Cherry Valley, New York. The occurrence of Monograptus praehercynicus in the Indian Point Formation, coupled with the presence of 


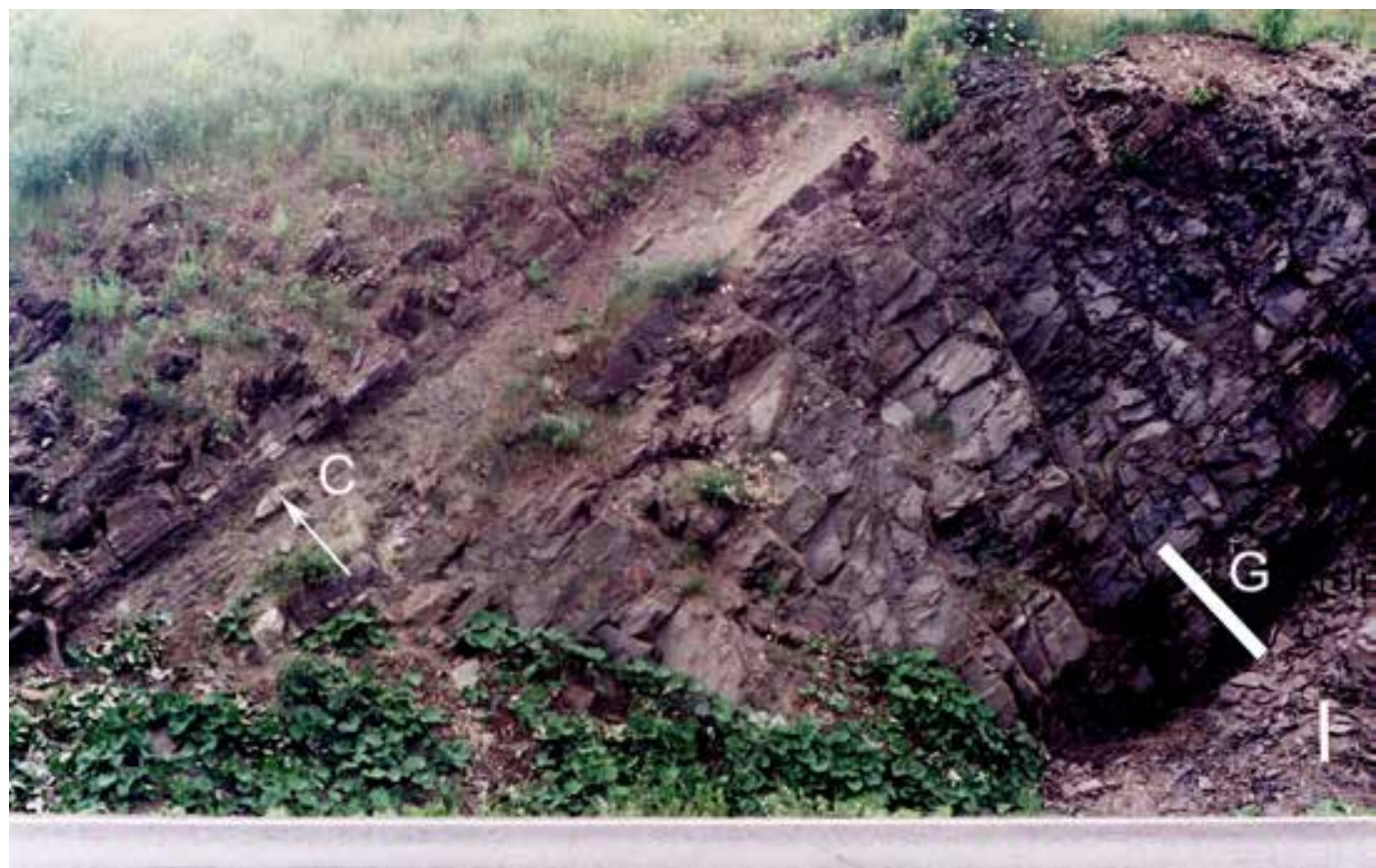

Figure 10. Upper portion Petit Portage Member of the Indian Point Formation showing tephra D group with concretions (labeled C) and graptolite-bearing beds (labeled G). Scale bar at lower right is one metre.

multiple tephras, strongly suggests correlation of the Indian Point Formation with the tephra-bearing New Scotland Formation and possibly the uppermost Kalkberg Formation in New York and probably with the Corriganville-Mandata interval (i.e., Bald Hill Bentonites of Smith, Berkheiser and Way 1988) in Pennsylvania.

Ver Straeten (2004a, b; Ver Straeten et al. 2012) interpreted four clusters of K-bentonites in the Appalachian Basin as representing peaks of explosive volcanic activity associated with the Silurian-Devonian Acadian Orogeny in the northern Appalachians. These clusters occur in the Lochkovian ( 417 Ma, Bald Hill cluster), Emsian (408 Ma, Sprout Brook cluster), Eifelian (391 Ma Tioga Middle Coarse Zone and 390 Ma Tioga A-G clusters). An additional cluster, the Belpre (381 Ma), was added by Ver Straeten (2010). Because of the biostratigraphically established age of the Lac au Renard Tephra Cluster, the following discussion will focus solely on the Lochkovian cluster and possible intrusive equivalents in the Acadian orogen.

Magmatism associated with the Acadian orogeny varies in composition from mafic lamprophyre to highly silicic rhyolite (Soper and Woodcock 2003; Brown et al. 2008). Because the Acadian orogen was dismembered with the opening of the modern Atlantic Ocean, Acadian-age plutons and effusive accumulations occur in New England, the United Kingdom, Ireland, and Iberia (Woodcock et al. 2007). Most accounts describe magmatic peaks in the Late Silurian $(\sim 420$ $\mathrm{Ma}$ ) and the late Early Devonian (Emsian; $405 \mathrm{Ma}$ ), separated by a period of transtension that included magmatism.

Ver Straeten et al. (2012) offered an expansive attempt to link several tephra clusters with specific deformational/ magmatic events in the Acadian orogen. However, it is likely that tectonism on the Laurentian margin was more or less continuous from $470 \mathrm{Ma}$ (i.e., Taconic orogeny) to $270 \mathrm{Ma}$ (Karabinos in Ver Straeten et al. 2012). Karabinos (in Ver Straeten et al. 2012) suggested that the Bald Hill cluster is of approximately the same age as the Standing Pond Volcanic Member of the Waits River Formation (423 $\pm 4 \mathrm{Ma}$ ) and a felsic sill in the Barnard Volcanic Member of the Missisquoi Formation $(419 \pm 1 \mathrm{Ma})$. These units are associated with Late Silurian rifting in the incipient Connecticut Valley, Merrimack and Gaspe troughs (the Tobique volcanic belt of Dostal et al. 1989 and Keppie and Dostal 1994). Karabinos (2019) reported zircon U-Pb ages of approximately 419 to $405 \mathrm{Ma}$ for detrital zircons from the Waits River, Gile Mountain, and Northfield/Goshen formations, a range of ages that also overlaps with the Bald Hill Cluster in the Appalachian Basin. For the Gaspe through New England regions, this extensional deformation, associated volcanism, and emplacement of granitic plutons were described by Tremblay and Pinet (2005). The Late Silurian to Early Devonian volcanic rocks of this region were reported as mainly basalts related to intra-plate processes.

Hon et al. (1991) described the Piscataquis volcanic belt of Maine as Silurian to Early Devonian. Within the Piscataquis belt, the $3000 \mathrm{~m}$ thick Traveler Rhyolite was shown by these authors to range from middle Lochkovian to the end of the Emsian (Hon et al. 1991). Rankin and Tucker (1995) indicated that the Katahdin/Traveler suite is younger (407 Ma), a date later referred to the Emsian (e.g., Bradley and Tucker 2002). Schoonmaker et al. (2005) accepted the age of $407 \mathrm{Ma}$ (Emsian) for the Katahdin/Traveler igneous complex, which is clearly too young to correlate with the Lac au Renard tephras. However, the older parts of the Piscataquis belt 


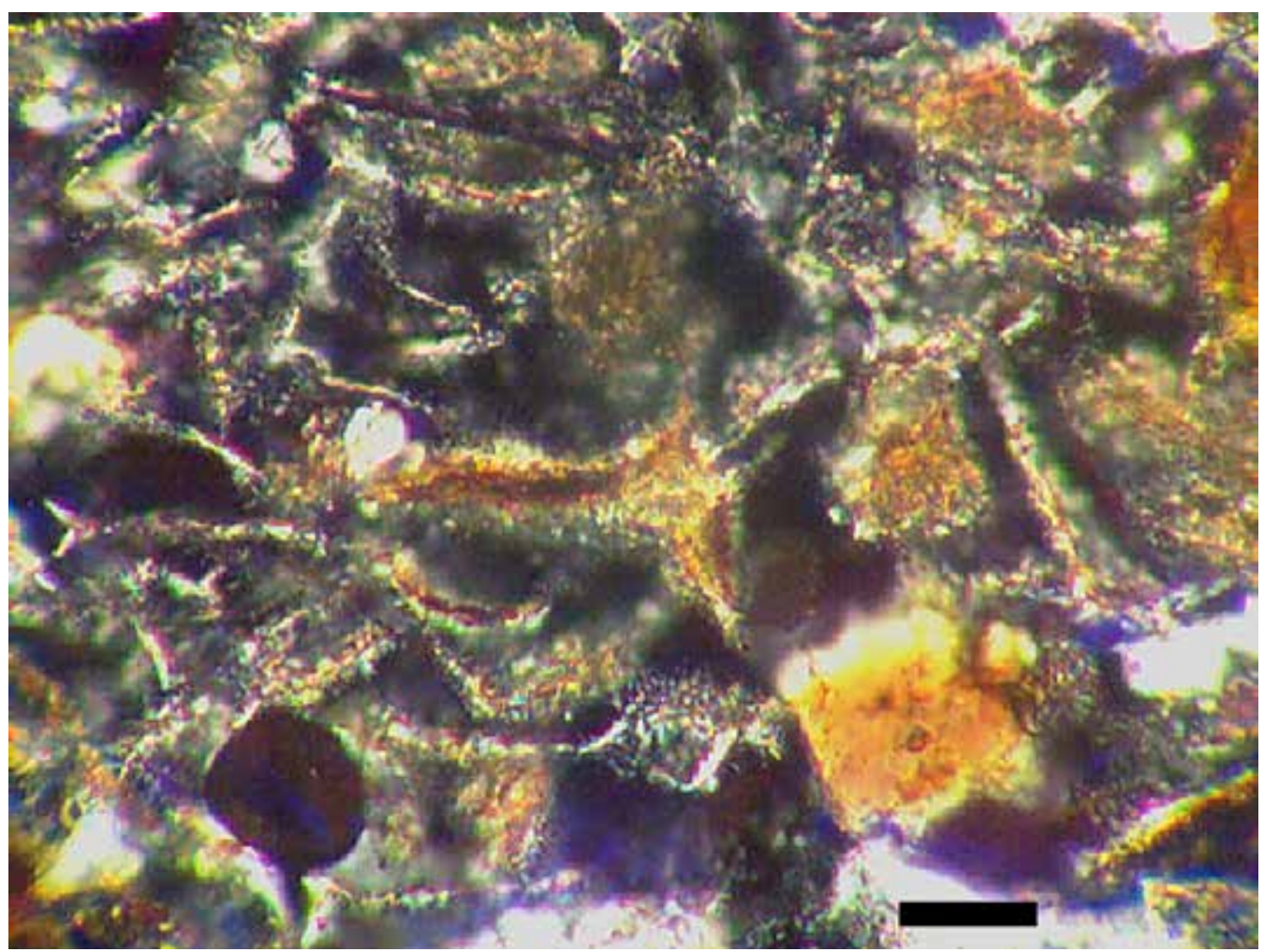

Figure 11. Photomicrograph of hypocrystalline texture, preserved from compaction by early cementation in a concretion in tephra group D. Microphenocrysts and trilete, devitrified glass shards are present. The thin section was etched with dilute hydrochloric acid to remove the equant spar of the concretion in order to highlight the pyroclastic components. Scale bar is approximately $0.1 \mathrm{~mm}$.

(Hon et al. 1991) likely overlap in age with the Lac au Renard Tephra Cluster of Gaspe.

Llamas and Hepburn (2013) reported that the Coastal Volcanic belt of Maine consists of Silurian-Devonian volcanic rocks related to the collision of Avalonia with Laurentia, just before and during the early stages of the Acadian orogeny. Though the tectonic setting of these volcanic rocks is unclear (volcanic arc on Avalon, volcanic arc on Ganderia, or related to extension), at least some of the igneous bodies overlap in age with the Lac au Renard Tephra Cluster. Bradley et al. (2000) reported $\mathrm{U}-\mathrm{Pb}$ ages for several plutons in the Coastal Volcanic belt (Avalonia) in Maine that are similar in age to the Lochkovian Lac au Renard and Bald Hill tephra clusters. These include the Cadillac pluton (419 $\pm 2 \mathrm{Ma})$, the Lincoln shonkinite $(417.7 \pm 1 \mathrm{Ma})$, the Northport pluton $(419.0 \pm 2 \mathrm{Ma})$, the Sedgwick pluton (419.5 $\pm 1.4 \mathrm{Ma})$, the South Penobscot pluton $(419.2 \pm 2.2 \mathrm{Ma})$, and the Youngstown pluton $(420.0 . \pm 2 \mathrm{Ma})$. Similar ages were reported by Tucker et al. (2001) for the Northport and Youngstown plutons. These authors also described Ludlow to Emsian volcanism in the Piscataquis belt and Ludlow to Lochkovian ages for the East Branch Group, the West Branch Volcanics, and the Fish River, Spider Lake, Grand Lake Seboesis and Allagash Lake formations (Bradley et al. 2000). Although the Lincoln shonkinite is closest in age to the dated tephras from the Helderberg Group (Tucker et al. 1998; Husson et al. 2015; McAdams et al. 2017), and poten- tially the Lac au Renard cluster, the alkaline mafic composition of the Lincoln shonkinite (West et al. 2007) is incompatible with the felsic tephras.

Intra-plate volcanism occurred in the Gaspe region during two intervals: Pridoli to middle Lochkovian (419-411 Ma) and middle Pragian to lower Emsian (411-400 Ma) (Malo 2001). The composition of the Pridoli to middle Lochkovian volcanic rocks was reported as intermediate to basaltic, so it is unlikely that these volcanic centers were responsible for the Lac au Renard Tephra Cluster. However, Bourque et al. (2000) mentioned minor rhyolite and pyroclastic rocks from the Dalhousie Formation in the Maria Belt of southern Gaspe.

Late Silurian to Early Devonian paleogeography is rather poorly constrained owing to the possibility that several peri-Gondwanan terranes were involved in AppalachianCaledonian orogenesis. Therefore, the following presents examples of Late Silurian to Early Devonian magmatism in more distant areas (present geography) that we feel are relevant to the discussion. We emphasize that this will not be an exhaustive review of Late Silurian to Early Devonian magmatism in the Appalachian-Caledonide system, but rather it provides context for our assertion that numerous regions experienced felsic magmatism during deposition of the Indian Point Formation and the included Lac au Renard Tephra Cluster.

Kellett et al. (2014) reported a SHRIMP date of $423 \pm 4 \mathrm{Ma}$ 


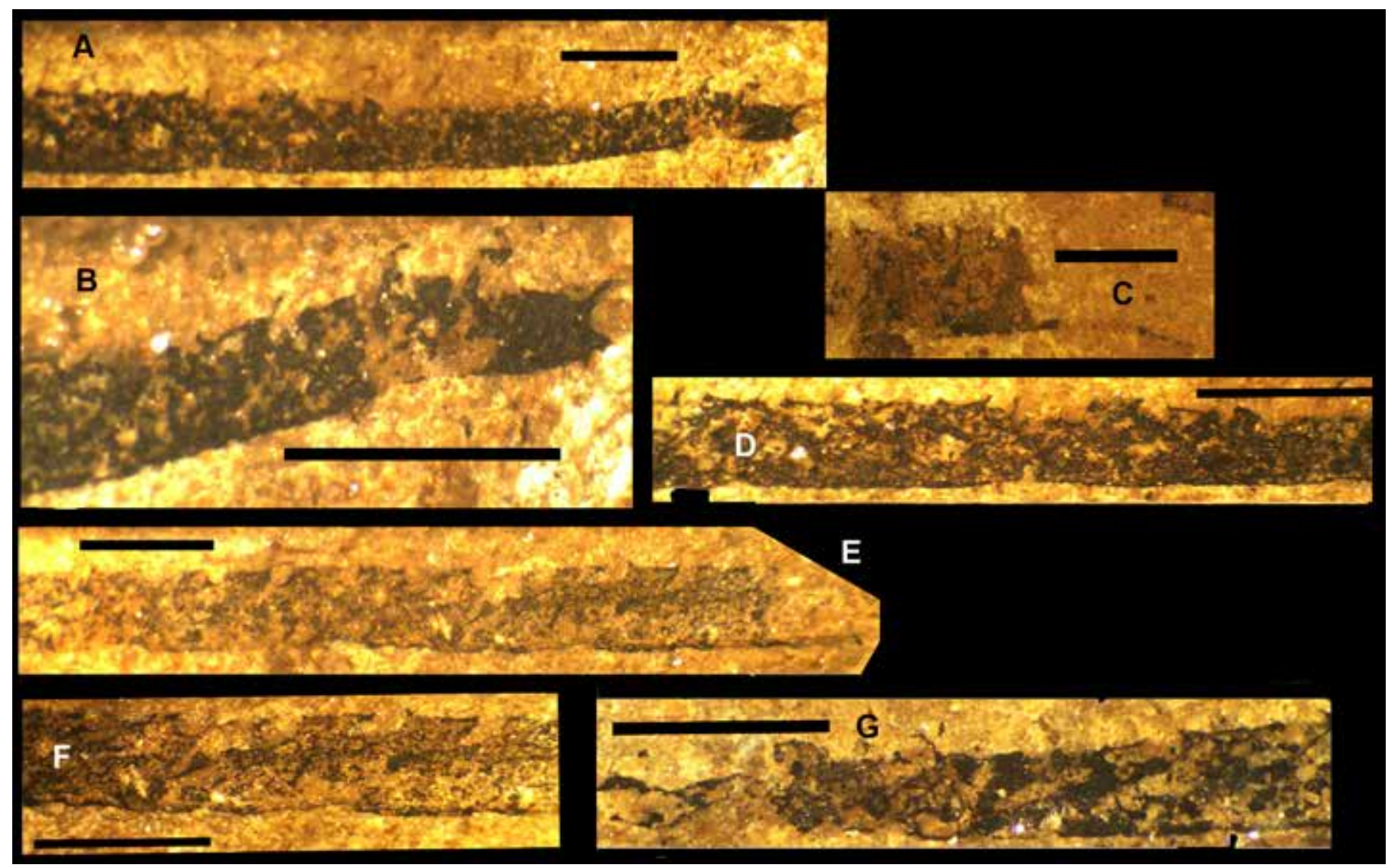

Figure 12. Graptolites from the upper portion of the Petit Portage Member of the Indian Point Formation of the Chaleurs Group. (a) a rhabdosome of the middle Lochkovian index graptolite Monograptus praehercynicus. (b) an enlarged image of the proximal end of Monograptus praehercynicus rhabdosome shown in Figure 12a. The sicula and shape of thecae are visible. (c) the distal end of Monograptus praehercynicus with nema (d) an enlargement of the middle section of the Monograptus praehercynicus rhabdosome shown in Figure 12a and b. (e) a nearly complete rhabdosome of Monograptus aequabilis ssp., a Lochkovian index graptolite. ( $\mathrm{f}$ ) an enlarged view of the curved thecae of the specimen of Monograptus aequabilis ssp., shown in Figure 12e. (g) a poorly preserved specimen of Monograptus aequabilis ssp. with damaged sicula and poorly defined thecae. Scale bar in each image is $2 \mathrm{~mm}$.

for the Pass Island granite on the border between the Avalon and Gander terranes in Newfoundland, Canada. In the Canadian Arctic Islands, Dewing et al. (2019) report orogenesis in the Boothia Uplift during the Late Silurian to Early Devonian ( 426-410 Ma). Although Dewing et al. (2019) do not mention magmatism specifically, the age of orogenic activity in the Canadian Arctic islands includes the age of the Lac au Renard Tephra Cluster from Gaspe. Detrital zircons (416 $\pm 6 \mathrm{Ma}$ ) from the Arisaig Group of Nova Scotia indicate coeval volcanism in Baltica during deposition of the Arisaig Group (Murphy 2004).

Across the Atlantic Ocean, Histon et al. (2007) reported K-bentonites of Pridoli and Lochkovian age from the Carnic Alps. Magmatic activity associated subduction beneath Avalon ranging from $420 \mathrm{Ma}$ to $400 \mathrm{Ma}$ has been reported (Woodcock et al. 2007), though magmatism during this interval has also been interpreted as a result of transtensional tectonics between the Caledonian and Acadian orogenic episodes (Brown et al. 2008). These authors described intrusive ages from $435 \mathrm{Ma}$ to $380 \mathrm{Ma}$ in northern England, southern
Scotland and Ireland. Similarly, Dewey et al. (2015) reported that the Newer Granites of Scotland ranged from $447 \mathrm{Ma}$ to $380 \mathrm{Ma}$, reflecting multiple tectonic events. In the Midland Valley of England, Brown et al. (2008) show volcanism that is mainly Lochkovian, but which continued through the Pragian (their fig. 3). Woodcock et al. (2018) and Miles and Woodcock (2018) described the long history of the Shap granite resulting from multiple intrusions from $428 \mathrm{Ma}$ to $403 \mathrm{Ma}$, with a mean age of $415.6 \pm 1.4 \mathrm{Ma}$. These ages correspond to Late Silurian through Emsian activity. The mean age is late Pridoli, which predates the $417.61 \pm 0.50 \mathrm{Ma}$ age of the Judds Falls tephra in the Helderberg Group of New York (McAdams et al. 2017). However, this range of ages does overlap with the age of the Lac au Renard tephras.

In Ireland, Meighan et al. (2003) dated the Newry granite at $423 \pm 7 \mathrm{Ma}$ and Selby et al. (2004) and Feely et al. (2007) described an age range of 425-405 Ma for the Galway granites. Fritschle et al. (2018) reported multiple episodes of intrusion for the Leinster granitic batholith, the oldest of which is $417.4 \pm 1.7 \mathrm{Ma}$. The Lochnager and Etive plutons of 
Scotland yielded ages of 424-413 Ma and 423-407 Ma, respectively (Appleby 2007 and Appleby et al. 2008 as cited in Fritschle et al. 2018). Andesitic and dacitic volcanism at the Glencoe caldera (Scotland) has been dated at around $419 \mathrm{Ma}$ (Nielson et al. 2009). The Glencoe magmatism includes the Clach Leathad pluton (417.9 $\pm 0.9 \mathrm{Ma})$ and fault-related intrusions $(419.6 \pm 5.4 \mathrm{Ma})$ and the afore mentioned Etive dyke swarm ( 418-414 Ma) (Nielson et al. 2009). Nielson et al. (2009) reported a younger date for the Etive Pluton of $414.9 \pm 0.7 \mathrm{Ma}$ and they suggest linkage of the Glencoe rocks with the Shetland and Donegal "Newer Granites" of the Grampian Belt.

From the preceding discussion, it is apparent that felsic magmatism of Lochkovian age was common through much of the northern Appalachian-Caledonide system. Any one, or possibly several, of these magmatic centers could have been the source of the Lac au Renard and potentially correlative Bald Hill tephra clusters, including the Judds Falls Bentonite. Lacking radiometric dates and geochemical fingerprints (Huff 2016) for the Lac au Renard Tephra Cluster, it is not feasible at this point to correlate these tephras with a specific source.

Owing to the thickness and abundance of the Lac au Renard tephras, it is reasonable to conclude that northeastern Gaspe was located in a proximal position relative to the volcanic source. Similarly, the thinner, coeval Bald Hill tephras occupied a more distal position relative to the eruptive source (Ebert and Matteson 2003). Although numerous plate reconstructions for this time interval have been published, most lack the detail necessary to locate these tephra clusters relative to plutonic and volcanic occurrences of similar age.

As pointed out by Ver Straeten (2004a), prevailing winds are a principal factor in determining the distribution of volcanic airfall debris. Without detailed paleogeographic and paleo-wind reconstructions, it is not possible at this time to state whether the Bald Hill tephras were deposited directly downwind from the Lac au Renard tephras or whether they were located in a more lateral position relative to the volcanic source or more distally located from a separate source.

\section{DISCUSSION AND IMPLICATIONS}

The combination of zonal graptolites with the Lac au Renard Tephra Cluster in the Rosebush Cove and Petit Portage members of the Indian Point Formation should prove useful for Lower Devonian time-scale calibration. Based on radiometric age determinations from zircons in the Judds Falls Bentonite in the New Scotland Formation at Cherry Valley New York, the age of the Silurian-Devonian boundary was estimated at $418 \mathrm{Ma}$ (Tucker et al. 1998). A weighted mean ${ }^{207} \mathrm{~Pb} /{ }^{206} \mathrm{~Pb}$ age of $417.6 \pm 1 \mathrm{Ma}$ was obtained from zircon grains from this tephra bed (Tucker et al. 1998). Kaufmann (2006) accepted this age but increased the error bars by $2 \mathrm{Myr}$. Zircon grains from the Judds Falls Bentonite were also dated by later workers with ages reported as $417.68 \pm 0.52 \mathrm{Ma}$
(Husson et al. 2015; their sample H1-1) and 417.61 $\pm 0.12 \mathrm{Ma}$ (McAdams et al. 2017). If our correlations between Gaspe and New York are correct, then the $417.6 \mathrm{Ma}$ age is better constrained biostratigraphically to the concurrent range zone of Monograptus aequabilis ssp., Monograptus praehercynicus and the conodont Icriodus woschmidti (However, see cautionary note of Carls et al. 2007 regarding this conodont.). If our correlations should prove to be incorrect, then a new opportunity for time-scale calibration is presented by the Lac au Renard Tephra Cluster in the Indian Point Formation. Radiometric age determinations from zircon-bearing tephras of the Indian Point Formation would be well constrained biostratigraphically and could help refine the estimated age of the Silurian-Devonian boundary (see Gradstein et al. 2012). It is also worth noting that De Vleeschouwer and Parnell (2014) demonstrated that interpolated ages for boundaries on the time scale have greater uncertainty than the radiometrically dated ashes on which they are based. These authors suggest that the Silurian Devonian boundary should be reported as $418.8 \pm 2.7 \mathrm{Ma}$. However, De Vleeschouwer and Parnell (2014) followed Tucker et al. (1998) and assumed a lower Lochkovian age, near the Silurian-Devonian boundary, for the dated teph$\mathrm{ra}$ and did not recognize the middle Lochkovian age of the Judds Falls Bentonite (McAdams et al. 2017). Bevington et al. (2010) suggested that the age of the Silurian-Devonian boundary could be as old as $420 \mathrm{Ma}$, an age certainly well within the range suggested by De Vleeschouwer and Parnell (2014).

Consistent with that of earlier workers based on brachiopods, our biostratigraphy indicates that Lac au Renard Tephra Cluster of the Indian Point Formation probably correlates with middle Lochkovian tephras in the New Scotland Formation of New York. Correlation of tephra event beds gives further support to the biostratigraphic linkages of brachiopod and graptolite zonations described by Johnson and Murphy (1969) for the Appalachian Standard Succession of New York. Geochemical confirmation of the correlation of tephra beds from the Indian Point Formation to the tephras in the Helderberg Group in New York could provide the first direct physical correlation of globally standard graptolite zones to the "Appalachian Standard Succession" (the Devonian sequence of New York).

\section{CONCLUSIONS}

At least nineteen tephra beds, comprising the Lac au Renard Tephra Cluster, occur in the Rosebush Cove and Petit Portage members of the Indian Point Formation (Chaleurs Group) of eastern Gaspesie. Mineralogically and texturally graded phenocryst accumulations at the bases of many of the thicker tephras and preservation of ichnofossil microtopography argue for rapid, single-event emplacement of many of the Lac au Renard tephras but some of the Lac au Renard tephras have more complex depositional histories. Precompaction concretions have preserved original hypocrystalline 
textures, though glass shards have devitrified.

A middle Lochkovian (Lower Devonian) age is assigned to the upper portion of the Lac au Renard Tephra Cluster based on the presence of monograptids of the praehercynicus zone, though it is entirely possible that the lower portions of the section on Route 197 may be early Lochkovian or even latest Pridolian. Probable correlation of the Lac au Renard Tephra Cluster with tephras in the New Scotland Formation (Helderberg Group) of New York has significant implications for Lower Devonian geochronology. A U-Pb age from zircon in one of the Helderberg tephras has already been used to revise the age of the Silurian-Devonian boundary (Tucker et al. 1998; Kaufmann 2006; Husson et al. 2015; McAdams et al. 2017). Correlation of the tephras of the Indian Point Formation may further constrain the biostratigraphic position of the dated tephra from New York. Alternatively, if a correlation with strata in New York cannot be demonstrated, the Lac au Renard Tephra Cluster of the Indian Point Formation provides new candidates for $\mathrm{U}-\mathrm{Pb}$ age determination close to the Silurian-Devonian boundary.

\section{ACKNOWLEDGMENTS}

We thank Eric Natel for his assistance in the field, Alf Lenz for his confirmation of DKM's graptolite identifications, and Denis Lavoie for invaluable assistance with the literature, regional stratigraphy of Gaspe and his willingness to answer our many e-mail questions. Art Palmer reviewed an earlier version of this paper and provided helpful suggestions. We especially thank Chuck Ver Straeten and Editor Dave West for their thorough and incisive comments that greatly improved this paper.

\section{REFERENCES}

Achab, A. and Asselin, E. 1993. Upper Silurian and Lower Devonian chitinozoan microfaunas in the Chaleurs Group, eastern Canada. Special Papers in Palaeontology, 48, pp. 7-15.

Appleby, S.K. 2007. The origin and evolution of granites: An in-situ study of zircons from the Scottish Caledonian intrusions. Unpublished Ph.D. thesis, University of Edinburgh, Scotland, $316 \mathrm{p}$.

Appleby, S.K., Graham, C.M., Gillespie, M.R., Hinton, R.W., Oliver, G.J.H., and EIMF 2008. A cryptic record of magma mixing in diorites revealed by high-precision SIMS oxygen isotope analysis of zircons: Earth and Planetary Science Letters, 269, p. 105-117. https://doi.org/10.1016/j. epsl.2008.02.006

Berry, W.B.N. 1965. Comments on graptolites: Silurian stratigraphy of Gaspe Peninsula, Quebec, Discussion. Bulletin of American Association of Petroleum Geologists, 49, pp. 2303-2305. https://doi.org/10.1306/a6633894-16c0$11 \mathrm{~d} 7-8645000102 \mathrm{c} 1865 \mathrm{~d}$

Bevington, K.S., Ebert, J.R., and Dufka, P. 2010. Early De- vonian (Lochkovian) chitinozoan biostratigraphy of the lower Helderberg Group, Appalachian Basin, New York State and the age of the "Kalkberg" K-bentonite. Geological Society of America Abstracts with Programs, 42, p. 136.

Bishuk, D., Jr., Applebaum, R., and Ebert, J.R. 1991. Storm-dominated shelf and tidally-influenced foreshore sedimentation, Upper Devonian Sonyea Group, Bainbridge to Sidney Center, New York. In New York State Geological Association Field Trip Guidebook. Edited by J.R. Ebert. New York State Geological Association 63rd Annual Meeting, State University of New York College at Oneonta, Oneonta, New York, October 18-21, 1991, pp. 413-462.

Boucot, A.J. 1965. Silurian stratigraphy of Gaspe Peninsula, Quebec, Discussion: Bulletin of American Association of Petroleum Geologists, 49, pp. 2295-2316. https://doi. org/10.1306/a6633894-16c0-11d7-8645000102c1865d

Boucot, A.J., Cumming, L.M., and Jaeger, H. 1967. Contributions to the age of the Gaspe Limestone. Geological Survey of Canada Paper 67-25, 36 p. https://doi. org/10.4095/100908

Bourque, P.A. 1975. Lithostratigraphic framework and unified nomenclature for Silurian and basal Devonian rocks in eastern Gaspe Peninsula, Quebec. Canadian Journal of Earth Science, 12, pp.858-872. https://doi.org/10.1139/ e75-075

Bourque, P.A. 1977. Silurian and basal Devonian of northeastern Gaspe Peninsula: Ministere des Richesses Naturelles du Quebec, ES-29, 232 p.

Bourque, P.A., Amyot, G., Desrochers, A., Gignac, H., Gosselin, C., Lachambre, G., and Laliberte, J.Y. 1986. Silurian and Lower Devonian reef and carbonate complexes of the Gaspe Basin, Quebec - a summary. Bulletin of Canadian Petroleum Geology, 34, pp.452-489. https://doi. org/10.2113/49.2.299

Bourque, P.A., Brisebois, D., and Malo, M. 1995. Gaspe Belt. In Appalachian-Caledonian Orogen in Canada and Greenland. Edited by H. Williams. Geological Society of America, Geology of North America, F-1/Geological Survey of Canada, pp. 316-351. https://doi.org/10.1130/ dnag-gna-f1

Bourque, P.A., Malo, M., and Kirkwood, D. 2000. Paleogeography and tectono-sedimentary history at the margin of Laurentia during Silurian to earliest Devonian time: the Gaspe' Belt, Quebec. Geological Society of America Bulletin, 112, pp. 4-20. https://doi.org/10.1130/0016-760 6(2000) 112<4:pathat $>2.0 . \mathrm{co} ; 2$

Bradley, D.C. and Tucker, R.D. 2002. Emsian synorogenic paleogeography of the Maine Appalachians. Journal of Geology, 110, pp. 483-492. https://doi.org/10.1086/340634

Bradley, D.C., Tucker, R.D., Lux, D.R., Harris, A.G., and McGregor, D.C. 2000. Migration of the Acadian Orogen and foreland basin across the Northern Appalachians of Maine and adjacent areas. U.S. Geological Survey Professional Paper 1624, 64 p. https://doi.org/10.3133/pp1624

Brisebois, D. 1981. Geologie de la Region de Gaspe: Minis- 
tere de la Energie et des Resources, Rapport Interimaire, DPV-824, 19 p.

Brown, P.E., Ryan, P.D., Soper, N.J., and Woodcock, N.H. 2008. The Newer Granite problem revisited: a transtensional origin for the Early Devonian Trans-Suture Suite. Geological Magazine, 145, pp. 235-256. https://doi. org/10.1017/s0016756807004219

Burk, C.F., Jr. 1964. Silurian stratigraphy of Gaspe Peninsula, Quebec. Bulletin of the American Association of Petroleum Geologists, 48, pp. 437-464. https://doi. org/10.1306/bc743c05-16be-11d7-8645000102c1865d

Burk, C.F., Jr. 1965. Silurian stratigraphy of Gaspe Peninsula, Quebec: Reply to Discussion. Bulletin of the American Association of Petroleum Geologists, 49, pp. 2305-2316. https://doi.org/10.1306/a6633894-16c0$11 \mathrm{~d} 7-8645000102 \mathrm{c} 1865 \mathrm{~d}$

Carls, P., L. Slavík, and J. I. Valenzuela-Rios. 2007. Revisions of conodont biostratigraphy across the Silurian-Devonian boundary. Bulletin of Geosciences, 82, pp. 145-164. https://doi.org/10.3140/bull.geosci.2007.02.145

Chlupač, I., Lukes, P., Paris, F., and Schonlaub, H.P. 1985. The Lochkovian-Pragian boundary in the Lower Devonian of the Barrandian area (Czechoslovakia). Jahrbuch der Geologischen Bundesanstalt., 128, pp. 9-41. https:// doi.org/10.1127/nos/37/1999/75

Conkin, J.E. and Conkin, B.M. 1984. Paleozoic metabentonites of North America: Part 1. - Devonian metabentonites in the eastern United States and southern Ontario: their identities, stratigraphic positions, and correlations. University of Louisville Studies in Paleontology and Stratigraphy, 16, $136 \mathrm{p}$.

Cumming, L.H. 1959. Silurian and Lower Devonian formations in the eastern part of Gaspe Peninsula. Geological Society of Canada, Memoir 304, 45 p. https://doi. org/10.4095/100525

Davies, G.R. 1977. Turbidites, debris sheets, and truncation structures in upper Paleozoic deep-water carbonates of the Sverdrup Basin, Arctic Archipelago. In Deep-water carbonate environments. Edited by H.E. Cook P. Enos. Society of Economic Paleontologists and Mineralogists Special Publication, 25, pp. 221-247. https://doi.org/10.2110/ pec.77.25.0221

De Vleeschouwer, D. and Parnell, A.C. 2014. Reducing time-scale uncertainty for the Devonian by integrating astrochronology and Bayesian statistics: Geology, 42, pp. 491-494. https://doi.org/10.1130/g35618.1

Dewey, J.F., Dalziel, I.W.D., Reavy, R.J., and Strachan, R.A. 2015. The Neoproterozoic to Mid Devonian evolution of Scotland: a review and unsolved issues. Scottish Journal of Geology, 51, pp. 5-30. https://doi.org/10.1144/sjg2014$\underline{007}$

Dostal, J., Wilson, R.A., and Keppie, J.D. 1989. Geochemistry of Siluro-Devonian Tobique volcanic belt in northern and central New Brunswick (Canada): tectonic implications: Canadian Journal of Earth Science, 26, pp. 12821296. https://doi.org/10.1139/e89-108

Dewing, K., Hadlari, T., Pearson, D.G., and Matthews, W.
2019. Early Ordovician to Early Devonian tectonic development of the northern margin of Laurentia, Canadian Arctic Islands. Geological Society of America Bulletin, 131, pp. 1075-1094. https://doi.org/10.1130/b35017.1

Ebert, J.R. and Matteson, D.K. 2003. Distal Stratigraphic Effects of the Laurentia - Avalon Collision: A Record of Early Acadian (Pridoli-Lochkovian) Tectonism in the Helderberg Group of New York State, USA: Courier Forschungsinstitut Senckenberg, 242, pp. 157-167. https:// doi.org/10.1130/abs/2016ne-272351

Ebert, J.R., Applebaum, R.H.S., and Finlayson, H.C. 1992. K-bentonites and detrital mudstones in the Helderberg Group (L. Dev.), New York: implications for tectonic vs. eustatic cyclicity. Geological Society of America, Abstracts with Programs 24, p. 18.

Ebert, J.R., Johnson, E., Grimes, A., Routh, R., Pechenik, N., McCredy, R., and Bowler, J. 2007. The Kalkberg Formation (Helderberg Group, L. Dev., Lochkovian) at Cherry Valley, New York Is Actually New Scotland - Preliminary Results of Sedimentologic and Stratigraphic Investigations. Geological Society of America, Abstracts with Programs, 39, p. 60.

Ebert, J.R., Matteson, D.K., and Natel, E.M. 1997. A new suite of Lower Devonian K-bentonites from the Indian Point Formation of the Gaspe Peninsula, Quebec Appalachians: Geological Society of America, Abstracts with Programs, 29, , p. 43.

Feely, M., Selby, D., Conliffe, J., and Judge, M. 2007. Re-Os geochronology and fluid inclusion microthermometry of molybdenite mineralization in the late-Caledonian Omey Granite, western Ireland. Applied Earth Science, 116, pp. 143-149. https://doi.org/10.1179/174327507x207465

Fritschle, T., Daly, J.S., Whitehouse, M.J., McConnell, B., and Buhre, S. 2018. Multiple intrusive phases in the Leinster Batholith, Ireland: geochronology, isotope geochemistry and constraints on the deformation history. Journal of the Geological Society, 175, pp. 229-246. https://doi. org/10.1144/jgs2017-034

Gradstein, F.M., Ogg, J.G., Schmitz, M.D, and Ogg, G.M. 2012. The Geologic Time Scale, Volume 2 plus chart. Elsevier, Boston, USA, 1176 p. https://doi.org/10.1016/ b978-0-444-59425-9.05001-0

Hanson, B. 1995. A geochemical study of rhyolitic melt inclusions in igneous phenocrysts from Lower Devonian bentonites. Unpublished Ph.D. dissertation, State University of New York at Albany, $470 \mathrm{p}$.

Hanson, B., von Kiparski, W., and Delano, J.W. 1992a. Petrology and geochemistry of melt inclusions within quartz phenocrysts from Paleozoic K-bentonites. Geological Society of America Abstracts with Programs, 24, p. 176.

Hanson, B., Delano, J.W., von Kiparski, W., and Schirnick, C. 1992b. The occurrence of melt inclusions in quartz phenocrysts from K-bentonites in the Helderberg Group of New York State and their potential use in stratigraphic correlation. Geological Society of America Abstracts with Programs, 24, p 27.

Histon, K., Klein, P., Schonlaub, H.P., and Huff, W.D. 2007. 
Lower Paleozoic K-bentonites from the Carnic Alps, Austria: Austrian Journal of Earth Sciences, 100, pp. 2642.

Hon, R., Fitzgerald, J.P., Sargent, S.L., Schwartz, W.D., Dostal, J., and Keppie, J.D. 1991. Silurian-Early Devonian mafic rocks of the Piscataquis volcanic belt in northern Maine. Atlantic Geology, 28, pp. 163-170. https://doi. org $/ 10.4138 / 1858$

Huff, W.D. 2016, K-bentonites: A review. American Mineralogist, 101, pp. 43-70.

Husson, J.M., Schoene, B., Bluher, S., and Maloof, A.C. 2015. Chemostratigraphic and $\mathrm{U}-\mathrm{Pb}$ geochronologic constraints on carbon cycling across the Silurian-Devonian boundary. Earth and Planetary Science Letters, 436, pp. 108-120. https://doi.org/10.1016/j.epsl.2015.11.044

Jaeger, H. 1979. Devonian graptolithina. Special Papers in Palaeontology 23, pp. 335-339.

Johnson, J.G. and Murphy, M.A. 1969. Age and position of Lower Devonian graptolite zones relative to the Appalachian Standard Succession. Geological Society of America Bulletin, 80, pp. 1275-1282. https://doi.org/10.1130/00 16-7606(1969)80[1275:aapold]2.0.co;2

Karabinos, P. 2019. Stratigraphic, tectonic, and paleogeographic constraints on the Acadian Orogeny from detrital and igneous zircon dating of rocks from the Connecticut Valley-Gaspe Basin in Massachusetts and Vermont: Geological Society of America, Abstracts with Programs, 5. https://doi.org/10.1130/abs/2019ne-328130

Kaufman, B. 2006. Calibrating the Devonian Time Scale: A synthesis of U-Pb ID-TIMS ages and conodont stratigraphy. Earth Science Reviews 76, pp. 175-190. https://doi. org/10.1016/j.earscirev.2006.01.001

Kellett, D.A., Rogers, N., McNicoll, V., Kerr, A., and van Staal, C. 2014. New age data refine extent and duration of Paleozoic and Neoproterozoic plutonism at GanderiaAvalonia boundary, Newfoundland: Canadian Journal of Earth Science, 51, pp. 943-972. https://doi.org/10.1139/ cjes-2014-0090

Keppie, J.D. and Dostal, J. 1994. Late Silurian-Early Devonian transpressional rift origin of the Quebec Reentrant, northern Appalachians: Constraints from geochemistry of volcanic rocks: Tectonics, 13, pp. 1183-1189. https:// doi.org/10.1029/94tc01504

Lavoie, D. 1992. Lower Devonian facies in the Forillon Peninsula, Eastern Gaspe, Quebec Appalachians: a storm-influenced, carbonate outer shelf. Bulletin of Canadian Petroleum Geology, 4, pp. 303-320. https://doi. org/10.2113/49.2.346

Lenz, A.C. 1972. Graptolites from the Laforce and St. Leon formations, northern Gaspe, Quebec. Canadian Journal of Earth Science, 9, pp. 1148-1162. https://doi. org/10.1139/e $72-100$

Llamas, A. P. and Hepburn, J.C. 2013. Geochemistry of Silurian-Devonian volcanic rocks in the Coastal Volcanic belt, Machias-Eastport area, Maine: evidence for a pre-Acadian arc. Geological Society of America Bulletin, 125, p. 1930-1942. https://doi.org/10.1130/b30776.1
Logan, W.E. 1845. Report of Progress for the year 1843. In Geological Survey of Canada, Report of Progress, 1843, pp. 23-159.

Logan, W.E. 1846. Report of Progress for the year 1844. Geological Survey of Canada, Report of Progress, 1844, $110 \mathrm{p}$.

Logan, W.E. 1863. Progress Report from its commencement to 1863 ; illustrated by 498 wood cuts in the text, and accompanied by an atlas of maps and sections. Geological Survey of Canada, $983 \mathrm{p}$.

Malo, M. 2001. Late Silurian-Early Devonian tectono-sedimentary history of the Gaspe' Belt in the Gaspe' Peninsula: from a transtensional Salinic basin to an Acadian foreland basin: Bulletin of Canadian Petroleum Geology, 49, pp. 202-216. https://doi.org/10.2113/49.2.202

McAdams, N.E.B., Schmitz, M.D., Kleffner, M.A., Verniers, J., Vandenbroucke, T.R.A., Ebert, J.R. and Cramer, B.D. 2017. A new, high-precision CA-ID-TIMS date for the 'Kalkberg' K-bentonite (Judds Falls Bentonite). Lethaia. https://doi.org/10.1111/let.12241

McGerrigle, H.W. 1950. The geology of eastern Gaspe. Quebec Department of Mines, Geological Report, 35, 168 p.

Meighan, I.G., Hamilton, M.A., Gamble, J.A., Ellam, R.M., and Cooper, M.R. 2003. The Caledonian Newry Complex, NE Ireland: New U-Pb ages, a subsurface extension and magmatic epidote. Geological Society of America, Abstracts with Programs, 35, p. 79.

Miles, A.J. and Woodcock, N.H. 2018. A combined geochronological approach to investigating long lived granite magmatism: the Shap granite, U.K. Lithos, 304-307, pp. 245-257. https://doi.org/10.1016/j.lithos.2018.02.012

Milunich, K.C. and Ebert, J.R. 1993. Conodonts and K-bentonites in the Helderberg Group (L. Dev., New York): an opportunity for time scale calibration in eastern North America. Geological Society of America, Abstracts with Programs, 25, p. 65.

Murphy, J.B., Fernandez-Suarez, J., and Jeffries, T.E. 2004. Lithogeochemical and $\mathrm{Sm}-\mathrm{Nd}$ and $\mathrm{U}-\mathrm{Pb}$ isotope data from the Silurian-Lower Devonian Arisaig Group clastic rocks, Avalon terrane, Nova Scotia: a record of terrane accretion in the Appalachian-Caledonide orogeny. Geological Society of America Bulletin, 116, pp. 1183-1201. https://doi.org/10.1130/b25423.1

Neilson, J.C., Kokelaar, B.P., and Crowley, Q.G. 2009. Timing, relations and cause of plutonic and volcanic activity of the Siluro-Devonian post-collision magmatic episode in the Grampian Terrane, Scotland: Journal of the Geological Society, 166, pp. 545-561. https://doi.org/10.1144/0016$\underline{76492008-069}$

Paris, F. 1981a. Les Chitinozoires dans le Paléozoique du Sud-Ouest de l'Europe (Cadre géologique, Etude systématique, Biostratigraphie): Société Géologique et Minéralogique de Bretagne, Rennes, 26, 496 p.

Paris, F. 1981b. Les Chitinozoires, in Morzadec, et al.: La tranchée de la Lezais Emsien supérieur du Massif Armoricain. Société Géologique et Minéralogique de Bretagne, Rennes, 24, pp. 55-75.

Paris, F., Laufeld, S., and Chlupač, I. 1981. Chitinozoa of 
the Silurian-Devonian boundary stratotypes in Bohemia: Sveriges Geologiska Undersokning, Serie Ca, 51, pp. 1-29.

Paris, F., Winchester-Seeto, T., Boumendjel, K., and Grahn, Y. 2000. Toward a global biozonation of Devonian chitinozoans: Courier Forschungsinstitut Senckenberg, 220, pp. 39-55.

Rankin, D.W. and Tucker, R.D. 1995. U-Pb age of the Katahdin-Traveler igneous suite, Maine, local age of the Acadian orogeny, and thickness of the Taconian crust: Geological Society of America, Abstracts with Programs, 27, pp. 224-225.

Rickard, L.V. 1962. Late Cayugan (Upper Silurian) and Helderbergian (Lower Devonian) stratigraphy in New York. New York State Museum and Science Service Bulletin 386, 157 p. https://doi.org/10.3133/b1243

Rickard, L.V. 1975. Correlation of the Silurian and Devonian rocks in New York State. New York State Museum and Science Service, Map and Chart Series no. 24, 16 p.

Russell, L. 1946/1976. Gaspe Limestone Series - Forillon Peninsula: Stratigraphy of the Gaspe Limestone Series, Forillon Peninsula, Cap-des-Rosiers Township; a description made in 1947. Ministere des Richesses Naturelles du Quebec, DP-347, 88 p.

Schoonmaker, A., Kidd, W.S.F., and Bradley, D.C. 2005. Foreland-forearc collisional granitoid and mafic magmatism caused by lower-plate lithospheric slab breakoff: The Acadian of Maine, and other orogens. Geology, 33, pp. 961-964. https://doi.org/10.1130/g21832.1

Selby, D., Creaser, R.A., and Feely, M. 2004. Accurate and precise $\mathrm{Re}-\mathrm{Os}$ molybdenite dates from the Galway Granite, Ireland: Critical comment on Disturbance of the ReOs chrononmeter of molybdenites from the late-Caledonian Galway Granite, Ireland by hydrothermal circulation. Geochemical Journal, 35, pp. 29-35. https:// doi.org/10.2343/geochemj.38.291

Shaw, G.H., Chen, Y.A., and Scott, J. 1991. Multiple K-bentonites in the Lower Devonian Kalkberg Formation - Cobleskill, NY. Geological Society of America, Abstracts with Programs, 23, p.126.

Smith, D.G.W. 1967. The petrology and mineralogy of some Lower Devonian bentonites from Gaspe, P.Q. The Canadian Mineralogist, 9, pp. 141-165.

Smith, D.G.W., Baadsgaard, H., Folinsbee, R.E., and Lipson, J. 1961. K/Ar age of Lower Devonian bentonites from Gaspe, Quebec, Canada. Bulletin of the Geological Society of America, 72, pp. 171-173. https://doi.org/10.1130/ 0016-7606(1961)72[171:aaoldb]2.0.co;2

Smith, R.C., II, Berkheiser, S.W., Jr., and Way, J.H. 1988. The Bald Hill bentonite beds: A Lower Devonian pyroclastic-bearing unit in the northern Appalachians. Northeastern Geology, 10, pp. 216-230.

Soper, N.J. and Woodcock, N.H. 2003. The lost Old Red Sandstone of England and Wales: a record of post-Iapetan flexure or Early Devonian transtension? Geological Magazine, 140, pp. 627-647. https://doi.org/10.1017/ $\underline{\text { s0016756803008380 }}$
Tremblay, A. and Pinet, N. 2005. Diachronous supracrustal extension in an intraplate setting and the origin of the Connecticut Valley-Gaspe' and Merrimack troughs, northern Appalachians. Geological Magazine, 152, pp. 7-22. https://doi.org/10.1017/s001675680400038x

Tucker, R.D., Bradley, D. C., Ver Straeten, C., Harris, A.G., Ebert, J.R., and McCutcheon, S.R. 1998. New U-Pb zircon ages and the duration and division of Devonian time. Earth and Planetary Science Letters, 158, pp. 175-186. https://doi.org/10.1016/s0012-821x(98)00050-8

Tucker, R.D., Osberg, P.H., and Berry, H.N. IV. 2001. The geology of part of Acadia and the nature of the Acadian Orogeny across central and eastern Maine: American Journal of Science, 301, pp. 205-260. https://doi. org/10.2475/ajs.301.3.205

Verniers, J., Nestor, V., Paris, F., Dufka, P., Sutherland, S.J.E., and Van Grootel, G. 1995. A global Chitinozoa biozonation for the Silurian: Geological Magazine, 132, pp. 651666. https://doi.org/10.1017/s0016756800018896

Ver Straeten, C.A. 2008. Volcanic Tephra Bed Formation and Condensation Processes: A Review and Examination from Devonian Stratigraphic Sequences: Journal of Geology, 116, pp. 545-557. https://doi.org/10.1086/591991

Ver Straeten, C.A. 2004a. K-bentonites, volcanic ash preservation, and implications for Early to Middle Devonian volcanism in the Acadian orogen, eastern North America. Geological Society of America Bulletin, 116, pp. 474-489. https://doi.org/10.1130/b25244.1

Ver Straeten, C.A. 2004b. Sprout Brook K-bentonites: New Interval of Devonian (Early Emsian?) K-bentonites in eastern North America. Northeastern Geology and Environmental Science, 26, pp. 298-305.

Ver Straeten, C.A. 2010. Lessons from the foreland basin: Northern Appalachian basin perspectives on the Acadian Orogeny. In From Rodinia to Pangea: the Lithotectonic record of the Appalachian Region. Edited by R.P. Tollo, M.J. Bartholomew, J.P. Hibbard, and P.M. Karabinos. Geological Society of America Memoir, 206, pp. 251-282. https://doi.org/10.1130/2010.1206(12)

Ver Straeten, C., Ebert, J.R., Bartholomew, A., Shaw, G.H., Benedict, L.J., and Matteson, D.K. 2005. Devonian stratigraphy and K-bentonites in the Cherry Valley - Schoharie Valley Region. In Northeast Section of the Geological Society of America Fieldtrip Guidebook. Edited by D.T. Rodbell. $40^{\text {th }}$ Annual Meeting of the Northeast Section of the Geological Society of America, Saratoga Springs, New York, March 14-16, 2005, pp. D1-D57.

Ver Straeten, C.A., Baird, G, Karabinos, P., Samson, S., and Brett, C. 2012. Appalachian magmatism during the Ordovician and Devonian: perspectives from the foreland basin and the hinterland. In New York State Geological Association Field Trip Guidebook. Edited by T.E. Rayne. $84^{\text {th }}$ Annual Meeting of the New York State Geological Association, Hamilton College, Clinton, New York, September 28-30, 2012, pp. A7-1-60. https://doi.org/10.1130/ abs/2016ne-272712

West, D.P., Jr., Tomacak, P.B., Coish, R.A., Yates, M.G., and 
Reilly, M.J. 2007. Petrogenesis of the Lincoln Syenite, Maine: Late Silurian-Early Devonian melting of a source region modified by subduction driven metasomatism. American Journal of Science, 307, pp. 265-310. https:// doi.org/10.2475/01.2007.08

Woodcock, N.H., Soper, N.J., and Strachan, R.A. 2007. A Rheic cause for the Acadian deformation in Europe. Journal of the Geological Society, London, 164, pp. 1023
1036. https://doi.org/10.1144/0016-76492006-129

Woodcock, N.H., Soper, N.J., and Miles, A.J. 2018. Age of the Acadian deformation and Devonian granites in northern England: a review. Proceedings of the Yorkshire Geological Society. https://doi.org/10.1144/pygs2018-009

Editorial responsibility: David P. West, Jr. 